\title{
Remote sensing of coccolithophore blooms in selected oceanic regions using the PhytoDOAS method applied to hyper-spectral satellite data
}

\author{
A. Sadeghi ${ }^{1}$, T. Dinter ${ }^{1,2}$, M. Vountas ${ }^{1}$, B. Taylor ${ }^{2}$, M. Altenburg-Soppa ${ }^{2}$, and A. Bracher ${ }^{1,2}$ \\ ${ }^{1}$ Institute of Environmental Physics, University of Bremen, Bremen, Germany \\ ${ }^{2}$ Alfred-Wegener-Institute for Polar and Marine Research, Bremerhaven, Germany \\ Correspondence to: A. Sadeghi (sadeghi@iup.physik.uni-bremen.de)
}

Received: 30 September 2011 - Published in Biogeosciences Discuss.: 8 December 2011

Revised: 10 May 2012 - Accepted: 13 May 2012 - Published: 14 June 2012

\begin{abstract}
In this study temporal variations of coccolithophore blooms are investigated using satellite data. Eight years (from 2003 to 2010) of data of SCIAMACHY, a hyperspectral satellite sensor on-board ENVISAT, were processed by the PhytoDOAS method to monitor the biomass of coccolithophores in three selected regions. These regions are characterized by frequent occurrence of large coccolithophore blooms. The retrieval results, shown as monthly mean time series, were compared to related satellite products, including the total surface phytoplankton, i.e. total chlorophyll $a$ (from GlobColour merged data) and the particulate inorganic carbon (from MODIS-Aqua). The inter-annual variations of the phytoplankton bloom cycles and their maximum monthly mean values have been compared in the three selected regions to the variations of the geophysical parameters: sea-surface temperature (SST), mixed-layer depth (MLD) and surface wind-speed, which are known to affect phytoplankton dynamics. For each region, the anomalies and linear trends of the monitored parameters over the period of this study have been computed. The patterns of total phytoplankton biomass and specific dynamics of coccolithophore chlorophyll $a$ in the selected regions are discussed in relation to other studies. The PhytoDOAS results are consistent with the two other ocean color products and support the reported dependencies of coccolithophore biomass dynamics on the compared geophysical variables. This suggests that PhytoDOAS is a valid method for retrieving coccolithophore biomass and for monitoring its bloom developments in the global oceans. Future applications of time series studies using the PhytoDOAS data set are proposed, also using the new
\end{abstract}

upcoming generations of hyper-spectral satellite sensors with improved spatial resolution.

\section{Introduction}

\subsection{Importance of coccolithophores}

Phytoplankton play crucial roles in the marine food web and in the global carbon cycle. Sensitive responses of phytoplankton to the environmental and ecological impacts make them reliable indicators of the variations in climate factors. Coccolithophores are an abundant taxonomic group of phytoplankton with a wide range of effects on the oceanic biogeochemical cycles (Rost and Riebesell, 2004) and a significant influence on the optical features of surface water (Tyrrell et al., 1999). Coccolithophores also affect the atmosphere and climate by emitting dimethyl sulfide (DMS) into the atmosphere (Tyrrell and Merico, 2004; Andreae, 1990), where it is converted to the sulfur aerosols and cloud condensation nuclei $(\mathrm{CCN})$ and influence the climate and the Earth's energy budget (Charlson et al., 1987; Andreae, 1990). Among different phytoplankton blooms, coccolithophore blooms are very important due to their wide coverage and frequent occurrence (Holligan et al., 1983), as well as their unique biooptical and biogeochemical properties (Brown and Podesta, 1997; Balch, 2004). Coccolithophores are the main planktonic calcifiers in the ocean characterized by a build-up of calcium carbonate $\left(\mathrm{CaCO}_{3}\right)$ plates, called coccoliths (Westbroek et al., 1985). Through building and releasing coccoliths, coccolithophores make a major contribution to the 
total content of particulate inorganic carbon (PIC or suspended $\mathrm{CaCO}_{3}$ ) in the open oceans (Milliman, 1993; Ackleson et al., 1994). PIC represents about $1 / 4$ of all marine sediments (Broecker and Peng, 1982) and is regarded as a major oceanic sink for atmospheric $\mathrm{CO}_{2}$ and by this interacting with the rate of ocean acidification (Balch and Utgoff, 2009). In the same context, increased oceanic $\mathrm{CO}_{2}$, which is a response to the increase in atmospheric $\mathrm{CO}_{2}$ (anthropogenic contribution), affects the rate of calcification by coccolithophores by reducing the supersaturation state of the carbonate ion (Riebesell et al., 2000). Moreover, sinking through the water column and getting deposited in the sediment (either directly as coccoliths and detritus or after being converted into PIC), coccolithophores are considered to be one of the main drivers of the biological carbon pump (Raven and Falkowski, 1999; Rost and Riebesell, 2004; Thierstein and Young, 2004) and hence a key component of the global carbon cycle (Westbroek et al., 1993). Coccolithophores are known for frequently forming large-scale blooms, where due to the strong backscattering effect by their coccoliths (detached or attached), they influence the optical characteristics of the environment in two aspects: causing a high reflectance from the ocean surface; (and) making a large impact on the light field in upper ocean, by reducing the amount of available light beneath (Ackleson et al., 1988; Balch et al., 1989). The most dominant species within the coccolithophore taxonomic group is Emiliania huxleyi (E. huxleyi). E. huxleyi is known to be a significant producer of DMS (Keller et al., 1989b; Malin et al., 1992), which affects the planetary albedo (Charlson et al., 1987). Studies suggest that coccolithophore blooms, in their most recognized regions of occurrence, often succeed diatom blooms in response to increasing stabilization and nutrient depletion of surface waters (Margalef, 1978; Holligan et al., 1983; Lochte et al., 1993). Hence, monitoring coccolithophore blooms can also improve our understanding of the global distribution of diatoms. Some former studies aimed to exploit and develop remote sensing methods for monitoring the distribution of coccolithophores on a global scale (Groom and Holligan, 1987; Brown and Yoder, 1994a; Brown, 1995; Gordon et al., 2001), as well as studying corresponding blooms on regional scales (Balch et al., 1991; Holligan et al., 1993; Brown and Yoder, 1994b; Brown and Podesta, 1997; Smyth, 2004; Morozov et al., 2010).

\subsection{Background of the retrieval method}

Coccolithophores frequently form large blooms, which can be visually detected by satellite imagery. Surveying the distribution and development of marine phytoplankton on a global scale (Yoder et al., 1993; Sathyendranath et al., 2004; Alvain et al., 2005) has conventionally been done by retrieving aquatic chlorophyll $a$ concentrations ( $\mathrm{chl} a$ ), as an indicator of phytoplankton biomass (Falkowski et al., 1998). For ocean color remote sensing, several bio-optical empirical algorithms (e.g. OC4v4 by O'Reilly et al., 1998) and semi- analytical algorithms (Carder et al., 2004) have been developed, relying on water-leaving radiance detected by satellite sensors at two to five specific wavelength bands. However, due to the phytoplankton biodiversity and differences in the optical properties of phytoplankton groups, remote identification of different phytoplankton functional types (PFTs; see summary by Nair et al., 2008) with improved algorithms and new retrieval methods has recently been in the focus of research (Ackleson et al., 1994; Brown and Yoder, 1994a; Tyrrell et al., 1999; Gordon et al., 2001; Subramaniam et al., 2002; Sathyendranath et al., 2004; Alvain et al., 2005). The development of PFT-based retrieval methods will also improve the estimates of the total phytoplankton biomass and deepen the understanding of the oceanic biogeochemical cycles. Based on this demand, the PhytoDOAS method was established to discriminate major phytoplankton functional groups based on their specific absorption footprints on the backscattered radiation from the ocean (Bracher et al., 2009).

PhytoDOAS is an extension of differential optical absorption spectroscopy, DOAS (Perner and Platt, 1979; Platt, 1994), into the aquatic medium. By applying the PhytoDOAS method to hyper-spectral satellite data, provided by the SCIAMACHY sensor (on-board ENVISAT), the global distributions of two main phytoplankton groups, diatoms and cyanobacteria, have been derived. By improving the method through multi-target fitting, two more PFTs, coccolithophores and dinoflagellates have been distinguished recently (Sadeghi et al., 2011). To test this improvement, SCIAMACHY data from 2005 have been globally processed using the improved PhytoDOAS method. The success of coccolithophore retrieval was so far proven by comparisons with the global distribution of PIC, provided by MODIS-Aqua level-3 products and comparison with the coccolithophore modeled data obtained from NASA Ocean Biochemical Model, NOBM (Gregg et al., 2003; Gregg and Casey, 2007). In addition, two sample coccolithophore blooms, detected by satellite imagery, were identified by applying the improved PhytoDOAS to the SCIAMACHY data: one located around New Zealand, reported in December 2009 as a RGB image by MODIS (Sadeghi et al., 2011); and the other one in the North Atlantic in August 2004.

\subsection{Objectives}

The main interest of this study was to show the capability of the PhytoDOAS method for quantitative remote sensing of coccolithophores (using satellite data) and also its application for studying the phytoplankton dynamics, which is necessarily connected to the study of environmental factors. Due to the crucial role of coccolithophores in the global biogeochemical cycles, this satellite-based method can be used for monitoring temporal and spatial variations of coccolithophores on a global scale, which in turn can be used (in the context of phytoplankton dynamics) for studying the impacts of a varying climate on marine phytoplankton (Winder 
and Cloernet , 2010). To show this capacity, coccolithophore blooms in selected regions were monitored over eight years and their inter-annual variations were investigated along with the temporal variations of certain geophysical parameters. On the other hand, PhytoDOAS takes the following factors into account, which are often not considered in current biooptical methods based on band-ratio algorithms: the phytoplankton absorption spectra, the existence of multiple PFTs and the average in-water path-length of detected light (being correlated with the light penetration depth in water). Therefore, the above specific capabilities of the method are investigated by this study. More specifically, concerning coccolithophore retrieval, while other phytoplankton pigments cause a decrease in backscatter radiance mostly in the blue part (and slightly in the green), coccolithophores, due to their calcite plates, affect the solar irradiance uniformly in both the blue and the green (Gordon et al., 1988). Furthermore, as coccolithophore blooms cause flattening of the reflectance spectrum, the standard ratio pigment algorithms (Gordon and Morel, 1983) will not provide correct pigment retrievals within the blooms (Balch et al., 1989; Balch, 2004), whereas, by retrieving the differential absorption features, the PhytoDOAS method has the potential to obtain results on PFT chl $a$ in high coccolithophore regions, when hyperspectral variations are still visible. In this sense, retrieving coccolithophore blooms provides also a reliable application to test the improved PhytoDOAS method.

\section{Study setup}

\subsection{Initial tests and selection of regions}

Regarding the fact that the whole coccolithophore group cannot be observed through in-situ measurements, and also due to the data sparsity and limited temporal and spatial coverage associated with the coarse spatial resolution of SCIAMACHY, no direct comparison of retrieved to in-situ coccolithophores has been performed. More precisely, when analyzing water samples by microscopy, only the cells larger than $5 \mu \mathrm{m}$ can be identified, while cell diameters of coccolithophores range approximately from $2 \mu \mathrm{m}$ up to $10 \mu \mathrm{m}$. Also by the Continuous Plankton Recorder (CPR, see Raitsos et al., 2006), with the mesh size of about $270 \mu \mathrm{m}$, only parts of the total cells of coccolithophores are detectable, containing those captured on the finer threads of silk that constitute the mesh-weave (Hays, 1995). From HPLC and flow cytometric analysis, only the groups of haptophytes or nanoeukaryotes, respectively, can be identified, to both of which coccolithophores belong. Hence, coccolithophore group can not be observed properly (along with the cell concentration) through in-situ measurements. In addition, there is a significant difficulty associated with the collocation of the in-situ point measurements to the large SCIAMACHY ground pixels of $30 \mathrm{~km}$ by $60 \mathrm{~km}$ sizes. Therefore, with respect to coc- colithophores, the comparison presented in this paper is a satellite algorithm versus satellite algorithm approach. Practically, the PhytoDOAS coccolithophores were compared to the global distribution of PIC obtained from the MODISAqua level-3 products (after the preliminary comparisons with the NOBM coccolithophore modeled data). The reason behind this is, since PIC concentration is proportional to the suspended coccoliths in surface waters, it is regarded as the main indicator of coccolithophores (Balch et al., 2005). Very good agreements were observed in distribution patterns of coccolithophores and PIC on a monthly and seasonal basis (Sadeghi et al., 2011). Moreover, coccolithophore chl $a$ results were compared to the total chl $a$ (provided by GlobColour merged data), as the maximum limit of observed chl $a$ for coccolithophores. Figure 1 illustrates a sample comparison of these three products for August 2005, showing consistent patterns between coccolithophores (upper panel) and PIC (middle panel), followed by general similarities with the total chl $a$ (lower panel). The similarities observed between distribution patterns of coccolithophores and PIC are pronounced in the North Atlantic and North Pacific, but partial similarities are also seen in the Mid-Pacific, South Atlantic and northwest and southwest of the Indian Ocean.

To monitor the development of coccolithophore blooms, regions of high occurrence were selected based on the following procedure: first, a global distribution of coccolithophores, mapped by Brown and Yoder (1994a) and Brown (1995) was considered; secondly, eight years of global distribution of PIC (from MODIS-Aqua) were monitored as monthly composites; and finally coccolithophore field studies were analyzed (Brown and Podesta, 1997; Balch et al., 1991; Holligan et al., 1993; Garcia et al., 2011; Raitsos et al., 2006; Painter et al., 2010; Burns, 1977; Tilburg et al., 2002). Based on these pre-investigations, three regions have been selected (Fig. 2), located in the North Atlantic (south of Iceland), the South-west Atlantic (north of the Falkland Islands), and the South-west Pacific (south-west of New Zealand, in the Tasman Sea). For simplicity the regions were labeled as nAtl, sAtl and sPac, respectively. The regions were selected to be geographically $10^{\circ} \times 10^{\circ}$ areas, which regarding their latitudinal distributions means almost the same geometrical areas for sAtl and sPac and a slightly smaller area for nAtl. As shown in Fig. 2 on a background of the MODISAqua PIC product, two regions (sAtl and $\mathrm{sPac}$ ) are located in a wide latitudinal belt of elevated PIC concentrations. This area, characterized by an almost permanent high reflectance, has been hypothesized (Balch et al., 2005, 2011) to be associated with elevated coccolithophores, and hence is referred to as Great Calcite Belt. The Great Calcite Belt is located all the way around the Southern Ocean near the Subantarctic front and polar front (between about $30^{\circ} \mathrm{S}$ and $60^{\circ} \mathrm{S}$ ). To retrieve coccolithophore dynamics in selected regions, the PhytoDOAS method according to Sadeghi et al. (2011) was applied to SCIAMACHY data (from January 2003 to December 2010) for each study region. Absorption spectrum 

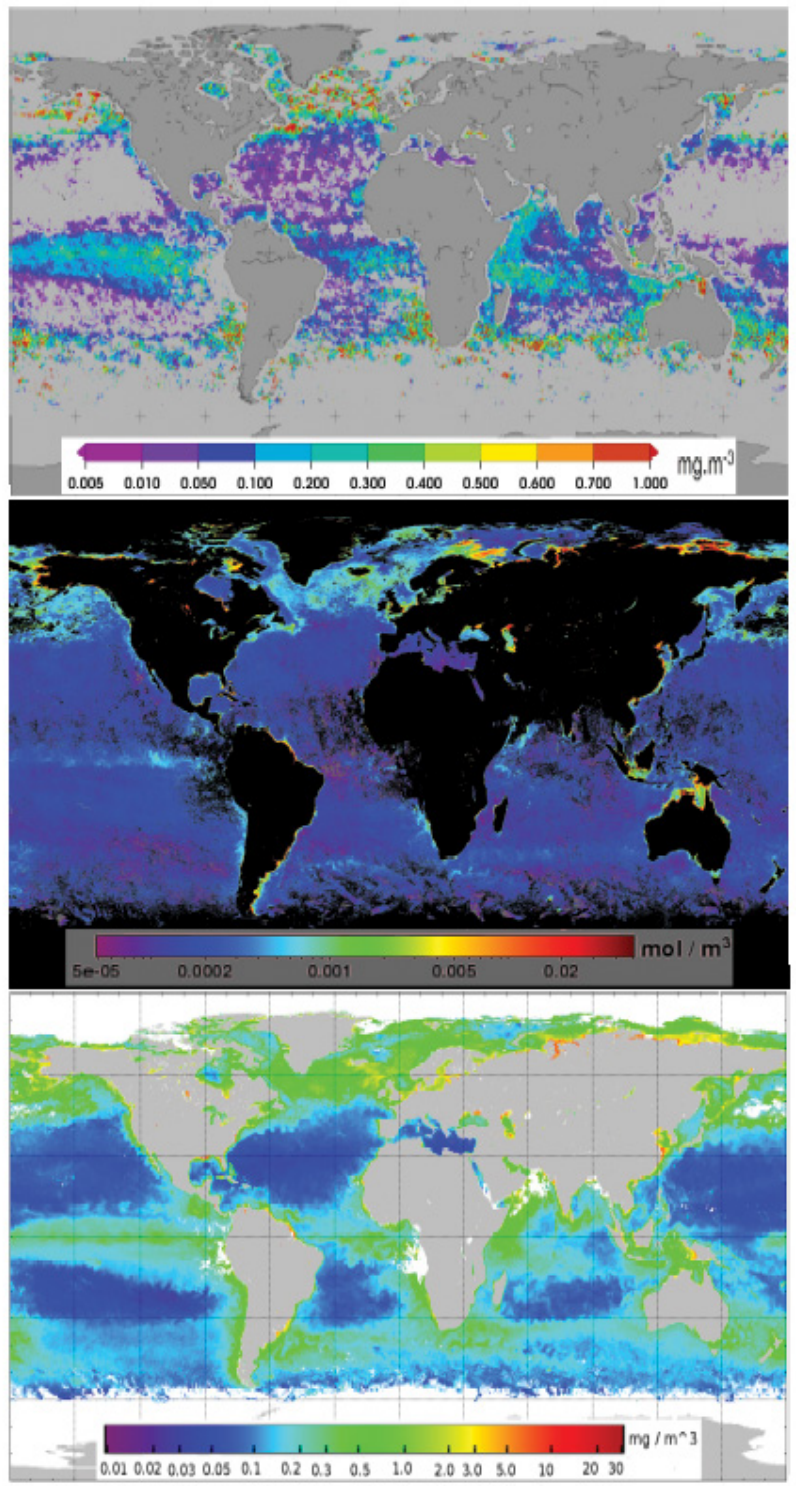

Fig. 1. A sample comparison of three monthly mean products, all obtained in August 2005: the PhytoDOAS coccolithophore chl $a$ (upper panel) retrieved from SCIAMACHY data, the PIC concentration (middle panel) from the MODIS-Aqua level-3 products, and the total chl $a$ (lower panel) from the GlobColour level-3 merged data.

of Emiliania huxleyi (E. huxleyi) was used for the coccolithophore target, because E. huxleyi is generally the dominant species in this group. The improved PhytoDOAS as well as the method principles and utilized reference spectra were explained in detail in Sadeghi et al. (2011) (the original version of the PhytoDOAS method was described in Bracher et al., 2009).

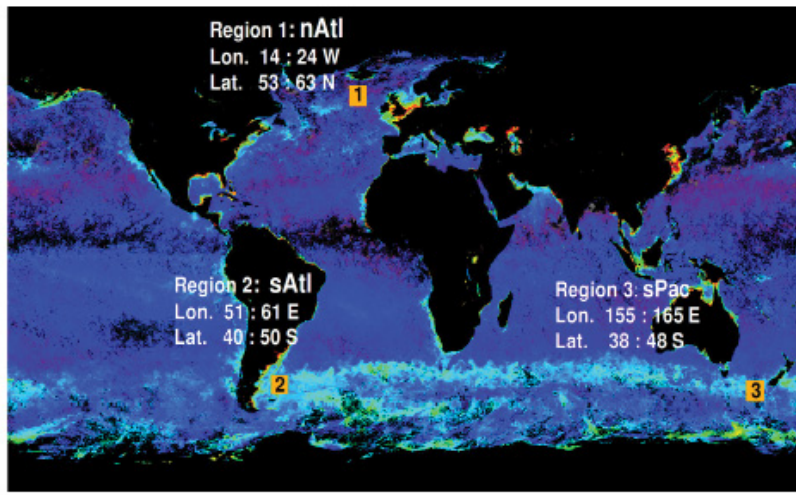

Fig. 2. Selected regions for monitoring the development of coccolithophore blooms in this study. Each region has the geographical size of $10^{\circ} \times 10^{\circ}$; regions 1,2 and 3 have been named as nAtl, sAtl and sPac, respectively. The background image shows the PIC monthly-mean conc. in March 2005 from the MODIS-Aqua level-3 products, demonstrating the so-called Great Calcite Belt as a bright greenish band above the Subantarctic regions.

\subsection{Satellite and modeled data}

Satellite data used in the PhytoDOAS method must be spectrally highly resolved. This requirement is met using the data collected by SCIAMACHY (SCanning Imaging Absorption spectroMeter for Atmospheric CHartographY), a sensor onboard ENVISAT (ENVIronmental SATellite of European Space Agency, ESA) launched in 2002. This sensor covers a wide wavelength range (from $240 \mathrm{~nm}$ to $2380 \mathrm{~nm}$ in 8 channels) with a relatively high spectral resolution, ranging from $0.2 \mathrm{~nm}$ to $1.5 \mathrm{~nm}$ (Bovensmann et al., 1999). In this study, nadir-viewing SCIAMACHY data in specific wavelength ranges of UV and visible were used, for which the spectral resolution ranges from $0.24 \mathrm{~nm}$ to $0.48 \mathrm{~nm}$. These data, used to build up the measured optical-depth, include backscattered radiation from oceanic surfaces (case-I waters), with a spatial resolution of about $30 \times 60 \mathrm{~km}^{2}$, and also solar radiation measured at the top of the atmosphere in the same wavelength range. Within PhytoDOAS, SCIAMACHY data were utilized at two wavelength ranges: first, the absorption spectra of the target PFTs were fitted using the visible data within the fit-window of $429 \mathrm{~nm}$ to $521 \mathrm{~nm}$; secondly, part of SCIAMACHY UV data (from $340 \mathrm{~nm}$ to $385 \mathrm{~nm}$ ) was used to estimate the average in-water path-length of detected light ray via retrieving the spectral signature of vibrational Raman scattering (VRS) of water molecules (Vountas et al., 2003, 2007). To compare and evaluate the coccolithophore retrieval results and to investigate their probable correlations with environmental factors, four other satellite products were collected for the selected regions from January 2003 to December 2010 as follows: (1) total chl $a$ from ESA's ocean-color dataset, GlobColour, providing merged data from three major ocean-color sensors: MODIS-Aqua, 
MERIS and SeaWiFS, with $4 \mathrm{~km}$ grid resolution (for details see: http://www.globcolour.info); (2) PIC conc. data from MODIS-Aqua level-3 products with $9 \mathrm{~km}$ grid resolution (see details on MODIS webpage: http://modis.gsfc. nasa.gov); (3) sea surface temperature (SST) from Advanced Very High Resolution Radiometer sensor (AVHRR: http: $/ / n$ nidc.org/data/avhrr) with a $4 \mathrm{~km}$ spatial resolution (from Pathfinder V5); and finally (4) surface wind-speed data derived from the Advanced Microwave Scanning RadiometerEarth Observing System (AMSR-E) sensor, globally gridded at $0.25^{\circ} \times 0.25^{\circ}$ (more information at http://remss.com).

The mixed-layer depth (MLD) monthly means (after June 2005) were obtained from the FNMOC (Fleet Numerical Meteorology and Oceanography Center) modeled data (http://orca.science.oregonstate.edu/1080.by.2160. monthly.hdf.mld.fnmoc.php). FNMOC's MLD is determined through the TOPS (Thermal Ocean Prediction) model by identifying the depth where the temperature is 0.5 degree lower than the value at the surface (the so-called isothermal layer depth, ILD). In general, apart from the high latitudes (above,$+-70^{\circ}$ ), the IDL is a good approximation of MLD. For the period before July 2005, the MLD data were obtained from the ocean productivity merged data set from the SODA (Simple Ocean Data Assimilation) model. The grid resolution of the MLD monthly data is $1 / 6$ degree.

\subsection{Further processing of the results}

The data of the different study parameters were represented as time series of monthly mean values within the same time period. PhytoDOAS results for all pixels within the selected regions were averaged for each month; MODIS-Aqua PIC data, AVHRR SST data and AMSR-E wind-speed data were directly collected as monthly-mean values; daily products of GlobColour total chl $a$ were converted into monthly mean values. Then, for each region, the time series of all six parameters were built up from January 2003 to December 2010. In the post-processing of the PhytoDOAS retrieved data, in order to remove the data points of poor quality, two criteria were applied: to filter out pixels with poor fit quality, only fit results with Chi-Square, $\chi^{2}$, values below 0.001 were used; and a threshold of ground pixel numbers was applied to the monthly-mean data to remove data points that were averaged over an insufficient number of remaining pixels (within a month). The minimum number of pixels (per month), for considering a monthly mean as an acceptable point, was determined by building an occurrence histogram, with the number of pixels per month as the random variable. Taking a coverage less than $10 \%$ of total occurrences as the lower limit, the threshold value was ranging, depending on the region, from 40 to 90 minimum observations per month.

It should be noted that, while ocean color observations in general cover only the surface waters, the PhytoDOAS retrieval results are the average value over the light path observed by the satellite. However, the signal measured by the satellite is not weighted equally by the different depths, and the surface concentrations are dominating the determined values. Therefore, one has to keep in mind that our study is focusing only on the surface water phytoplankton phenology.

\section{Results and discussion}

\subsection{Time series of biological and geophysical parameters}

The time series from January 2003 to December 2010 of all parameters over the three selected regions nAtl, sAtl and sPac are shown in Figs. 3, 4 and 5, respectively. These time series comprise monthly mean values of the following parameters: (a) coccolithophore chl $a$ (denoted by Coccos) retrieved by PhytoDOAS; (b) GlobColour total chl $a$; (c) PIC concentration from MODIS-Aqua; (d) MLD estimates from FNMOCO modeled data; (e) SST from AVHRR dataset; and (f) surface wind-speed from AMSR-E dataset. In the time series of the PhytoDOAS coccolithophores, there are some missing points due to times with poor data coverage or poor quality data, which have been specified via post-processing of the retrieved data.

These gaps in data, being inevitable to avoid artifact features, explain why the coccolithophore time series seem noncontinuous compared to the time series of the other parameters. The main reason for this anomaly is that SCIAMACHY (primarily designed for atmospheric missions), compared to the usual ocean color sensors (e.g. MODIS-Aqua, SeaWiFS and MERIS), has a very coarse spatial resolution $(30 \mathrm{~km} \times 60 \mathrm{~km})$. The characteristic of having large ground pixels makes its surface UV-visible data very sensitive to cloud contaminations, as compared to other sensors with high spatial resolutions. Therefore, the time series of PIC, provided by MODIS-Aqua, and the time series of total chl $a$, obtained from GlobColour merged data, show very few gaps. However, there are still enough data points in the coccolithophore time series, for comparing coccolithophore temporal variations with the other parameters.

In the time series of the nAtl region (Fig. 3), all parameters show a clear annual cycle; however, for some of the parameters (not for SST and MLD), the inter-annual cyclical periods of high intensities are deviating from one year to another. For example, from 2008 to 2009 for coccolithophores and PIC ,the period between the maxima is reduced to 10 months, while it is 11-14 for all other years (e.g. 2007 to 2008). However, for GlobColour total chl $a$ the intervals between successive maxima for the periods 2008/2009 and 2007/2008 are about 13 and 10 months, respectively. It can also be seen that the timings of the maximum conc. of coccolithophores, PIC and total chl $a$ are positively correlated. These maxima are negatively correlated with the MLD, as they should be, because the magnitude of coccolithophore surface biomass increases rapidly with shoaling of MLD (Raitsos et al., 2006). 


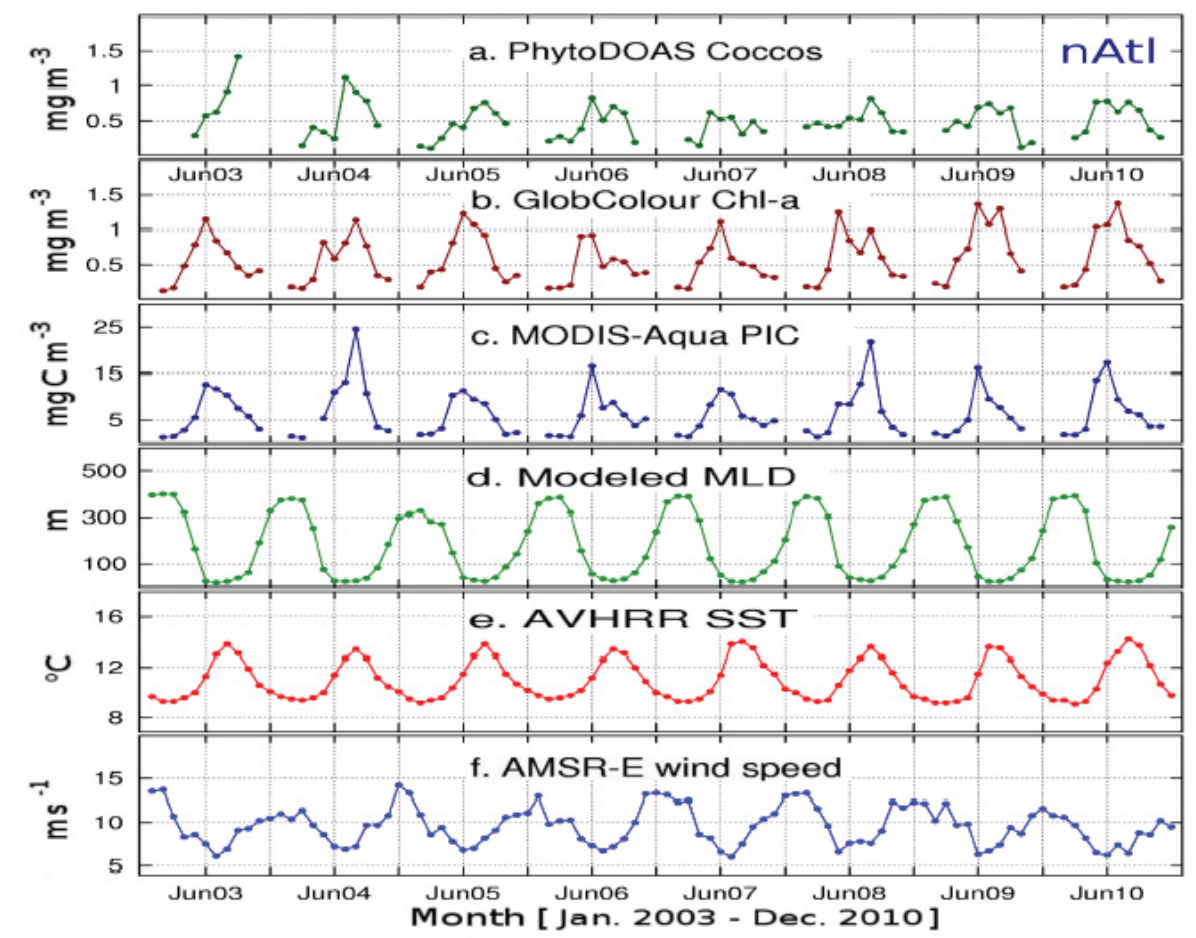

Fig. 3. Time series of six parameters monitored in nAtl from January 2003 to December 2010: (a) coccolithophore chl $a$ conc. retrieved by PhytoDOAS; (b) GlobColour total chl $a$; (c) MODIS-Aqua PIC conc.; (d) MLD from ocean productivity; (e) SST from AVHRR; and (f) surface wind-speed from AMSR-E.

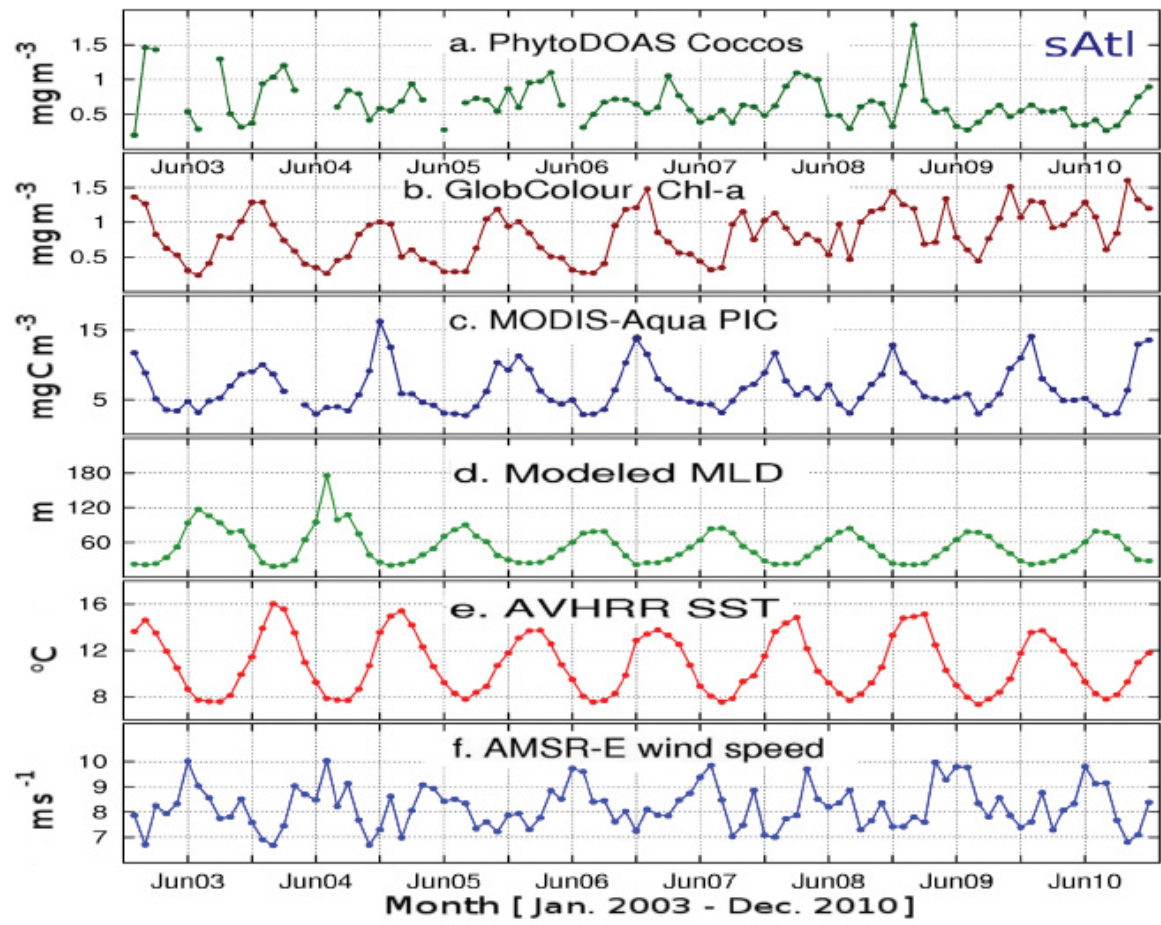

Fig. 4. Time series as described in Fig. 3, but for the sAtl region. 
More precisely, all three phytoplankton-based time series in Fig. 3 imply that the phytoplankton prosperity in surface waters is associated with a rapid decrease in MLD. Accordingly, surface phytoplankton biomass reaches its maximum when the seasonal period of shallow mixed-layer starts. The North Atlantic is often characterized by an extremely deep winter mixed layer and also a very low phytoplankton activity in wintertime (some recent studies, such as Boss and Behrnfeld (2010), have challenged this long-held belief). Both mentioned features can be seen clearly in Fig. 3. Low phytoplankton biomass in wintertime is usually attributed to the dramatic reduction in solar radiation, which in turn is reflected at the low SST values (shown too in Fig. 3). The phytoplankton and PIC maxima coincide with the high positive gradient of SST (i.e. SST-peaks always appear delayed compared to the phytoplankton peaks), which is in accordance with the results of Raitsos et al. (2006). Higher SSTs are associated with a stratified water column, which then leads to changes in the nutrient dynamics such as nutrient exhaustion. This can be pronouncedly observed over a period in summertime, when there is a significant gap of productivity between the spring bloom and the fall bloom. Theoretically, it is expected that the maxima of the three phytoplankton-based time series follow in a sequence, as the time elapses: total chl $a$ followed by coccolithophores and finally PIC, as coccolithophores start growing when the necessary nutrients for the growth or the survival of other species are scarce (Margalef, 1978; Holligan et al., 1983). On the other hand, the PIC concentration is expected to be proportional to the amount of coccoliths, which can be either attached to the living coccolithophores or detached from them and suspended in the water, even after the disappearance of the living coccolithophore cells. However, this sequence could not be reproduced in our time series, except for the year 2008. In fact, the peaks of total chl $a$ and PIC appear more or less at the same time, while coccolithophore peaks often follow the two former peaks with a slight delay. This systematic behavior might originate from the large monthly time interval used for averaging the retrieved products and setting up the coccolithophore time series (the lower subplots in Fig. 3, Fig. 4 and Fig. 5); The period of onemonth is probably larger than in reality because of the short life-time of phytoplankton cells (few days) and also changes in the environmental conditions, which might involve rapid changes in specific factors, due to the regional geophysical and biological characteristics. Therefore, weekly-based analysis would lead to a more precise investigation of the temporal rhythm of phytoplankton dynamics.

While the SST, the MLD and also the PIC conc. show clear annual cycles in the regions of sAtl and sPac (Fig. 4 and Fig. 5), the annual patterns for coccolithophores and total phytoplankton chl $a$ are much more irregular than in the nAtl (as coccolithophores are only a group of the phytoplankton, the total chl $a$ varies more smoothly than this specific group). These relative irregularities can be explained by the very dynamic wind-speed patterns observed in sAtl and sPac. As sur- face wind-stress forces the vertical motion in the water column (in addition to the horizontal motions or surface waves), it is affecting the stratification and the nutrient profile. It should be noted that strong surface winds, due to breaking waves, cause whiteness of the water surface, namely high reflectance. Within the PhytoDOAS retrieval, such pixels are flagged and not processed by the differential absorption method, because the spectral footprint of the wind-driven whitecaps is almost flat in the visible range (Koepke, 1984). Moreover, contrary to the hypothesis proposed by Zhang et al. (2002), suggesting that the storm-induced micro-bubble injection might explain the high reflectance in the so-called region of Great Calcite Belt (between the subtropical front and the northern part of the Subantarctic front), PhytoDOAS coccolithophore results at sAtl and sPac (both located within the Great Calcite Belt) prove that in these regions coccolithophores are indeed highly abundant (the same observation was reported by Eynaud et al. (1999) based on the results of a sampling cruise crossing this high reflectance area).

Regarding the sAtl region, there are several possible reasons for the irregular patterns of phytoplankton and PIC conc.:

- The general circulation in the sAtl is influenced by the interaction of two important ocean currents: the Malvinas (Falklands) current, transporting northwards Subantarctic cold and fresh waters and the Brazil current, carrying southwards subtropical saline and warm waters (Gordon, 1989; Spadone and Provost, 2009). The Brazil/Falklands confluence is an energetic and complex region of interaction and mixing of water masses (Brandini et al., 2000; Oliveira et al., 2009).

- The sAtl is located at the eastern part of the Patagonian Shelf, which is regarded as one of the richest areas of primary production (Bianchi et al., 2005, 2009; Schloss et al., 2007), and features recurring large coccolithophore blooms (Longhurst, 1995; Painter et al., 2010). The Patagonian Shelf, between $38^{\circ} \mathrm{S}$ and $51^{\circ} \mathrm{S}$, is located southwest of the confluence zone and therefore is affected by that. Apart from that, according to hydrography observations and satellite imagery (Saraceno et al., 2004; Bianchi et al., 2005; Romero et al., 2006), there are two other factors affecting the hydrography of the Patagonian Shelf: the shelf break front, which is a transition between the Malvinas current and shelf waters, existing in both winter and summer seasons (being stronger in the summer months) and the energetic tidal fronts, with pronounced seasonal variability, causing the vertical stratification of water masses (Sabatini et al., 2004; Bianchi et al., 2005).

- The non-cyclic aerosol-load and dust transport from the Patagonian Desert into the South Atlantic Ocean (atmospheric and riverine) affect the phytoplankton 


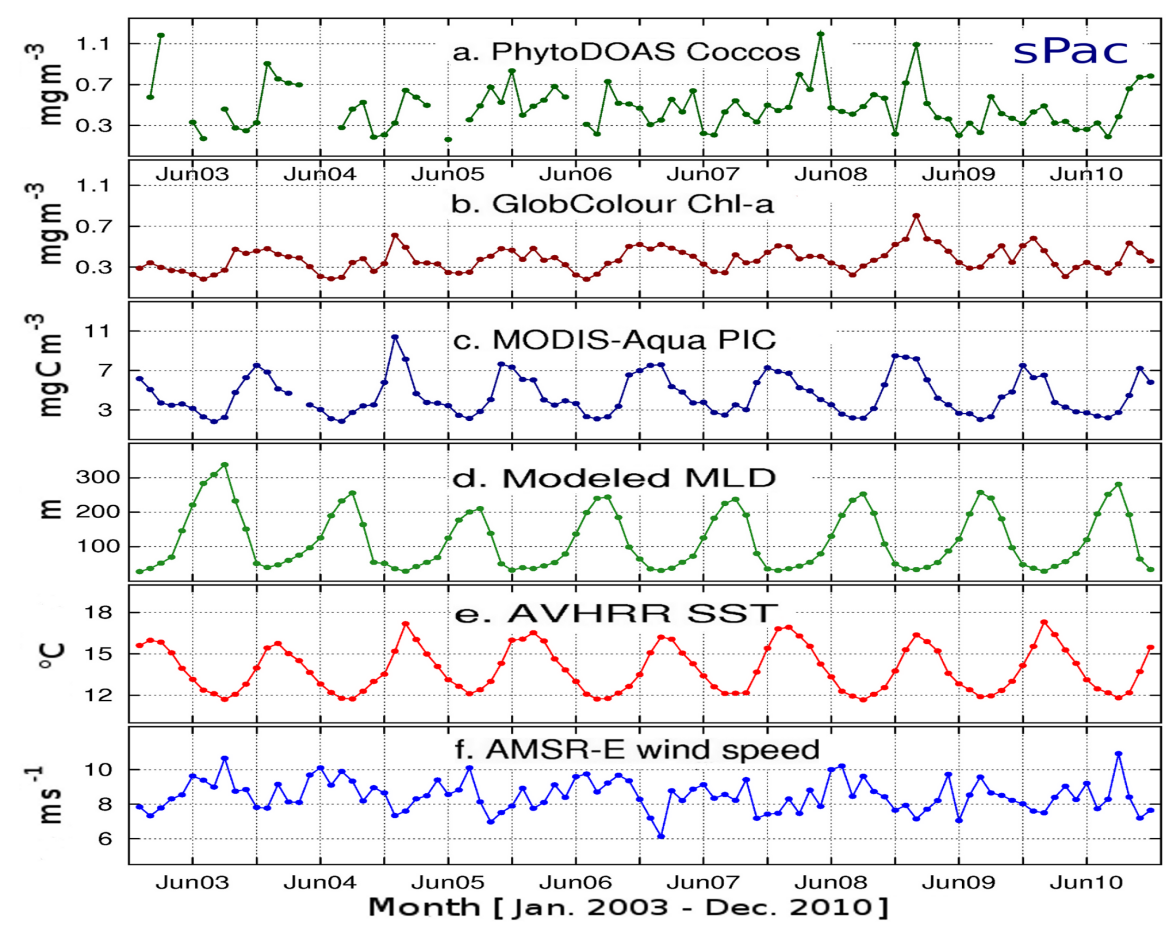

Fig. 5. Time series as described in Fig. 3, but for the sPac region.

productivity of the Patagonian Shelf by changing the nutrient regime (Erickson et al., 2003).

- The South Atlantic Anomaly (SAA) of the Earth's magnetic field affects most of satellite measurements over parts of South America and South Atlantic. Although the SAA region lies roughly between latitudes $5^{\circ} \mathrm{S}$ and $40^{\circ} \mathrm{S}$, its precise shape, size and strength varies with the seasons (http://sacs.aeronomie.be/info/saa.php). Hence, our sAtl region, residing between $40^{\circ} \mathrm{S}$ and $50^{\circ} \mathrm{S}$, could be partly affected by SAA.

The high variations and anomalies seen in the sPac time series can be attributed to its specific location, i.e. in the Tasman Sea. The Tasman Sea is one of the fastest warming areas in the Southern Hemisphere (Neuheimer et al., 2011; Ridgway, 2007), which is due to the specific local effects, such as the characteristic of the warm poleward waters of the East Australian Current (EAC) (Cai et al., 2005; Ridgway, 2007). Moreover, large eddies occurring in the Tasman Sea have a great contribution to the vertical mixing within the upper ocean. This increased mixing effectively counteracts the winter stratification and results in a varying chl $a$ seasonal cycle (Tilburg et al., 2002). In this sense, the seasonal cycle of chl $a$ in sPac should be pronounced, similar to the North Atlantic, which has very strong mixing, whereas the seasonality in the time series of GlobColour total chl $a$ for sPac is rather weak (less pronounced than in coccolithophores). This observation suggests a demand for a regional improvement of the chl $a$ algorithms from ocean-color sensors, at least for the Southwest Pacific.

In sPac, higher chl $a$ for coccolithophores than for the total phytoplankton is observed. Further investigations showed why the PhytoDOAS coccolithophore method is overestimating the coccolithophore chl $a$ (Fig. 5): studies (e.g. by Burns, 1977; Blackburn and Cresswell, 1993; Rhodes et al., 1995) showed that in the Tasman Sea and also around New Zealand (i.e. in sPac) the dominant coccolithophore species varies between E. huxleyi and Gephyrocapsa oceanica (G. oceanica), whereas, in this study the PhytoDOAS retrieval of coccolithophores was based on the specific absorption spectrum of E. huxleyi. Figure 6 illustrates the specific absorption spectra of these two coccolithophore species, G. oceanica and E. huxleyi, which were measured on cultures obtained from the isolation of these species from natural samples in different regions. As illustrated in Fig. 6, the specific absorption values of $G$. oceanica are much lower than the values of $E$. huxleyi. The reason is that the former species has, compared to $E$. huxleyi, much more chl $a$ pigment contents per cell. Hence, retrieving G. oceanica from a $E$. huxleyi specific absorption spectrum results in an overestimation of chl $a$ content. However, the similar absorption patterns of these two species ensure that the retrieval process can identify them as coccolithophore target. All together, these samples show variations in phytoplankton absorption within the same phytoplankton group, originating from their different geographical habitats. This feature and the different photo-acclimation, 


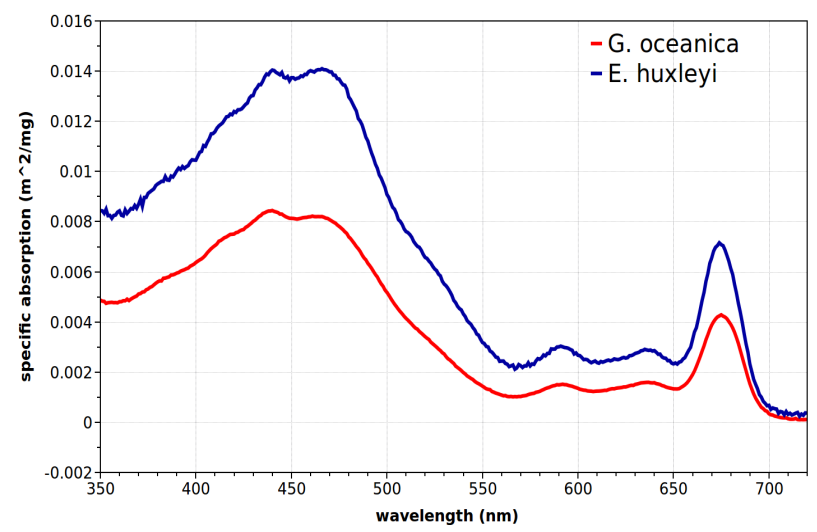

Fig. 6. Specific absorption spectra of two different coccolithophore species obtained from cultures: G. oceanica (red), isolated from the North Atlantic near the Portuguese coast; and E. huxleyi, isolated from the Tasman Sea in the South-west Pacific.

also changing the specific phytoplankton absorption, can affect the result of the PhytoDOAS retrieval.

The ratios of the GlobColour total chl $a$ to the PhytoDOAS retrieved chl $a$ of coccolithophores are depicted in Fig. 7 for the three study regions: the retrieved chl $a$ of coccolithophores are higher than GlobColour total chl $a$ in many months (which are illustrated by values less than one). Especially pronounced is this feature in the sPac region (lower panel). The reasons for the relatively higher coccolithophores for this region have already been discussed above. However, in nAtl and sAtl (upper and middle panels in Fig. 7, respectively), there are alternating patterns in the months, when the coccolithophore chl $a$ exceed the GlobColour total chl $a$. In both regions the coccolithophore chl $a$ exceed the total chl $a$ mostly after the summer bloom, i.e. after June in nAtl and for the austral summer in sAtl (except for the year 2010). Considering that these regions are characterized as high activity areas of coccolithophore blooms (Holligan et al., 1993; Raitsos et al., 2006; Painter et al., 2010; Garcia et al., 2011), along with the fact that the large reflectance from coccolithophore-rich surface waters affects the performance of the standard chl $a$ algorithms (Gordon et al., 1988; Ackleson et al., 1988; Balch et al., 1989; Balch, 2004), the overestimation of coccolithophores observed in Fig. 7 may be attributed to the proposed underestimation of chl $a$ during the coccolithophore blooms for the GlobColour data set. The reason for an overestimate in chl $a$ is because coccolithophores make fundamental changes to the band ratio algorithms: coccolithophores increase the radiance uniformly in both the blue and green (Gordon et al., 1988), leading to the flattening of the reflectance spectrum. This flattening effect is more pronounced over the coccolithophore blooms, implying that the standard ratio pigment algorithms (Gordon and Morel, 1983) will not provide correct pigment retrievals within the blooms (Balch et al., 1989).
The final validation of the coccolithophore chl $a$ will be part of a future study by comparison of the PhytoDOAS data product to a combination of the abovementioned in-situ measurements of coccolithophores.

\subsection{Interconnections between biological and geophysical parameters}

To investigate the driving factors behind the development and decline of coccolithophore biomass, the correlation coefficients between PhytoDOAS coccolithophore chl $a$ and all other parameters were computed (Fig. 8, left partitions of all panels). Similarly, the correlation coefficients between PIC conc. and the other parameters were determined (Fig. 8, right partitions).

In nAtl the retrieved coccolithophores correlated positively with the total chl $a$, PIC and SST, and negatively with MLD and surface wind-speed (upper left panel in Fig. 8). These results are in accordance with the reported dependence of coccolithophores on raising SST (or high surface irradiances), shallow MLD (or shallow stratification) and nonturbulent waters (Tyrrell and Taylor, 1996; Nanninga and Tyrrell, 1996; Raitsos et al., 2006), respectively. The correlation pattern of PIC conc. (Fig. 8 upper panel-right partition) was very similar to the PhytoDOAS coccolithophores, with close values of correlation coefficients (except being more highly correlated to the GlobColour total chl $a$ and being more inversely correlated to MLD). This similarity indicates the good agreement between the PhytoDOAS coccolithophores and the MODIS-Aqua PIC in nAtl.

However, in sAtl the retrieved coccolithophores were hardly correlated with total chl $a$ and PIC (Fig. 8, middle panel-left partition); possible reasons have been discussed before (Sect. 3.1). The correlations of coccolithophores with the geophysical parameters were weaker, compared to nAtl, but showing the same pattern. Moreover, despite the anomaly sources mentioned for this region, the correlation of coccolithophores with SST was similar to the situation in nAtl, which indicates again the vital importance of the rising SST (or high solar radiation) for occurring coccolithophore blooms. The correlations of PIC with other parameters in sAtl (middle-right panel) showed the same pattern and levels as in nAtl, but weaker with surface wind, which can be attributed to the complicated regimes of surface currents in this region as explained before.

In sPac (Fig. 8, lower panel-left partition) the correlations between coccolithophores and total chl $a$ and PIC were slightly better than in sAtl, but there was less dependence on SST and MLD. The latter feature can be attributed to the dynamic surface-wind patterns observed in this region, which is associated with the presence of large eddies in the Tasman Sea. These eddies, which originated from the separation of the EAC, migrate southwards into the Tasman Sea and cause regions of intense upwelling and downwelling (Tilburg et al., 2002), which results in turn in a strong seasonal cycle of 


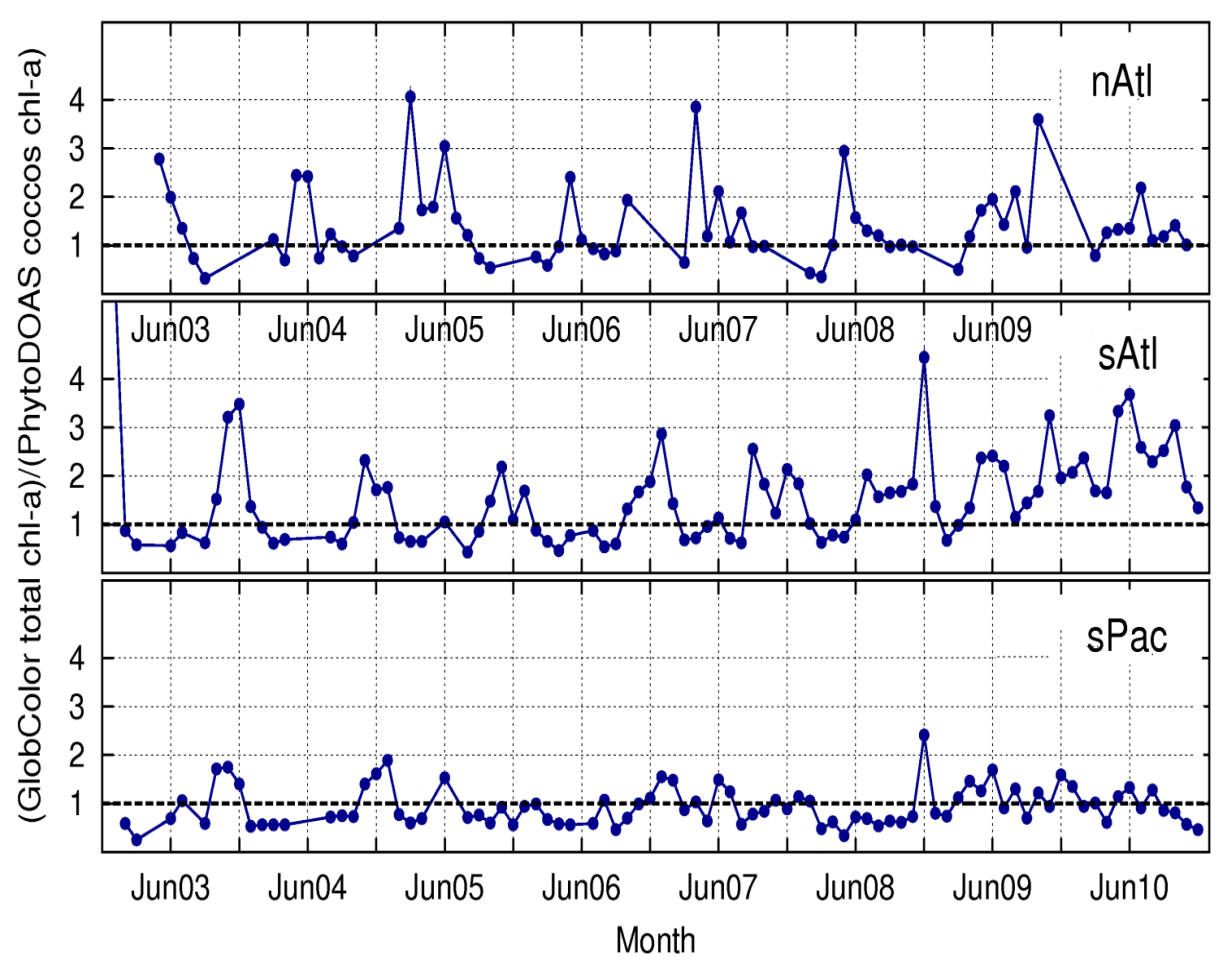

Fig. 7. Ratios of the GlobColour total chl $a$ to the PhytoDOAS retrieved chl $a$ of coccolithophores in three selected regions: nAtl (upper panel), sAtl (middle panel) and sPac (lower panel).

phytoplankton activity with the associated anomalies. Moreover, the specific floor topography of the Tasman Sea, i.e. the presence of an important mid-ocean ridge (van der Linden, 1969), and its effects on the surface currents and vertical motions of the water bodies should be kept in mind.

The highest correlation was observed between PIC conc. and GlobColour total chl $a$. This is not surprising as the algorithms of these two products use the reflectance information from the same wavelength-bands and both products are obtained from the high spatially resolved satellite data (in contrast to the coarse spatially resolved SCIAMACHY data). Moreover, MODIS-Aqua itself is one of the three ocean color sensors used by GlobColour project to provide the merged data (the other two sensors are SeaWiFS and MERIS).

As it is believed that coccolithophore blooms often follow diatom blooms (Margalef, 1978; Holligan et al., 1983; Lochte et al., 1993), time series of diatoms and coccolithophores for the study regions have been compared in Fig. 9. As shown in Fig. 9, diatoms demonstrate always higher chl $a$ contents in all regions, as it is expected (e.g. Goldman, 1993; Clark et al., 2002). However, while the temporal patterns of diatoms and coccolithophores in nAtl show clear differences, these differences are not as pronounced in sAtl and sPac. The following may explain these features: Firstly, in the sense of spatial and temporal appearances, coccolithophores and diatoms have some overlaps, due to their bloom successions. Accordingly, there should be some common habitats for the two PFTs, where their highly active periods are close to each other. This feature suggests a shorter averaging period to reach an improved identification, which can not be resolved by the current PhytoDOAS monthly products (based on the SCIMACHY data availability). As another side-effect of current averaging, monthly-mean chl $a$ maxima of coccolithophores and diatoms are probably smaller than the absolute maxima they reach during the blooms. Secondly, according to Eynaud et al. (1999), with respect to the distributions of diatoms and coccolithophores in the austral oceanic areas (including sAtl and sPac), there are complexities induced by the geostrophic circulation patterns of the Southern Ocean (e.g. Antarctic Circumpolar Current, ACC): the geostrophic circulation patterns of the Southern Ocean produce extended zones with relatively uniform hydrographic characteristics, inducing frontal boundaries (e.g. the Subantarctic, and the Antarctic Polar fronts). Furthermore, the frontal boundaries, which are areas associated with well- defined temperature changes, are believed to influence biological dispersal between and containment within these zones. Hence, due to the influence of geostrophic currents and frontal boundaries, there is no clear evidence for unique domains (on large scales) of single species blooms in the southern parts of austral waters. For instance, while some studies (e.g. Smetacek et al., 2002) suggest that the ACC 


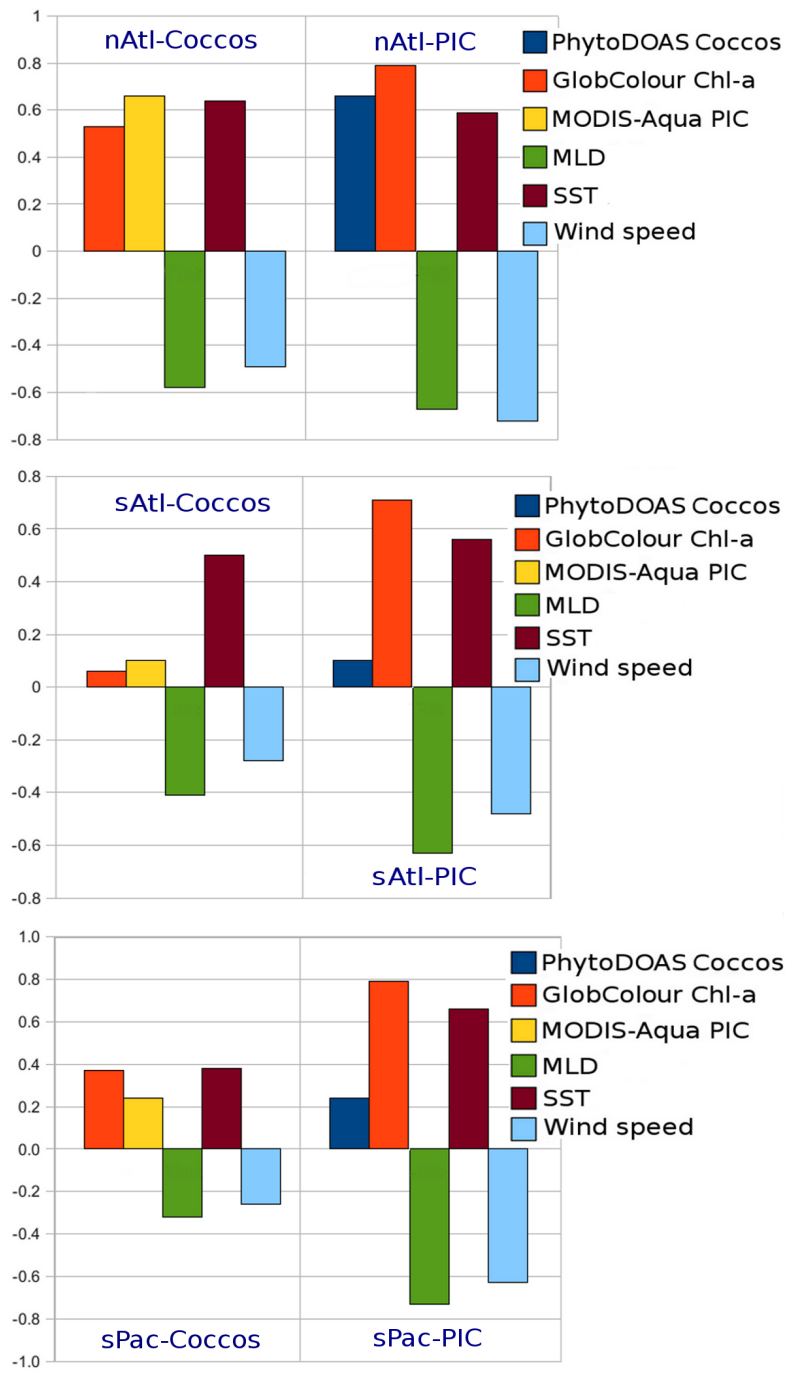

Fig. 8. Correlation coefficients between time series of PhytoDOAS coccolithophore chl $a$ (left partitions) and the other parameters in three investigated regions: nAtl (upper panel), sAtl (middle panel) and sPac (lower panel). Correlation coefficients between time series of PIC and the other parameters are depicted in the right partitions of the panels, respective to the three regions.

is dominated by diatoms and the Weddell Sea has abundant coccolithophores, there are other studies (e.g. Eynaud et al., 1999) suggesting that coccolithophores are also abundant in the northern regions adjacent to the Southern Ocean (where diatoms are dominating). Therefore, it might be that the large study areas $\left(10^{\circ} \times 10^{\circ}\right)$ selected in the Southern Hemisphere (i.e. sAtl and sPac) contain sub-areas affected by different fronts (or geostrophic currents) and hence, the selected area is covered simultaneously by diatoms and coccolithophores. This might also partly justify the similar patterns observed by PhytoDOAS for these two regions. Overall, it seems that utilizing smaller study regions and also shorter averaging periods (e.g. weekly-based averaging instead of monthly-based one) would lead to more distinguishable time series for diatoms and coccolithophores than what is shown in Fig. 9. However, these two options are not achievable by SCIAMACHY data due to its temporal data-sparsity and its coarse spatial resolution (as described before). Nevertheless, the application of PhytoDOAS to future hyper-spectral satellite sensors with improved spatial and temporal resolution will enable such analysis.

\subsection{Annual patterns of phytoplankton development associated with the evolutions of geophysical variables in selected regions}

Figure 10 illustrates the linear trends of five parameters for eight years of data (from 2003 to 2010) for the three study regions. It should be noted that the information extracted from this eight-year trend analysis is not highly promising, due to the relatively short period of monitoring. However, the analysis highlights that some results are consistent with the well-known relationships between the variables. For instance, when comparing the trends of different variables in nAtl and sAtl (Fig. 10, left panel), MODIS-PIC and GlobColour chl $a$ surprisingly do not show any change in the sign, while the trend signs of coccolithophores, SST and windspeed do change accordingly. Nevertheless, this trend analysis also aims to investigate an optimal approach for estimation of phytoplankton trend.

To reduce the effects of seasonality on the trend results, and to focus on the inter-annual variations of the parameters in phytoplankton prosperity seasons, only the months that cover the regional spring and summertime were taken into account. Additionally, the ocean color wintertime data only contain very few ground pixels per month, which also increases the uncertainty of the monthly mean values. Hence, for nAtl six months from April to September, and for sAtl and sPac seven months from September to March were considered. Linear regressions were computed for the monthly mean data (Fig. 10 left panel) and also for the anomaly time series data (Fig. 10 right panel). In the latter case each data point was obtained by subtracting the initial monthly mean (e.g. Jun. 2004) from the climatological mean of that particular month (i.e. mean value of all June months over eight years). We refer hereafter to these two approaches as simple trend and anomaly trend, respectively. No linear trends for MLD are shown in Fig. 10, because the MLD data, as modeled data, involve far more approximations than in the satellite-based retrieved products, which makes the comparison unsuitable. Moreover, the orders of magnitudes of the MLD trends are higher than the linear trends of the retrieved products, which could cause an illustration problem. Table 1 contains the MLD linear trends in three regions, which were calculated by both simple trend and anomaly trend approaches. 


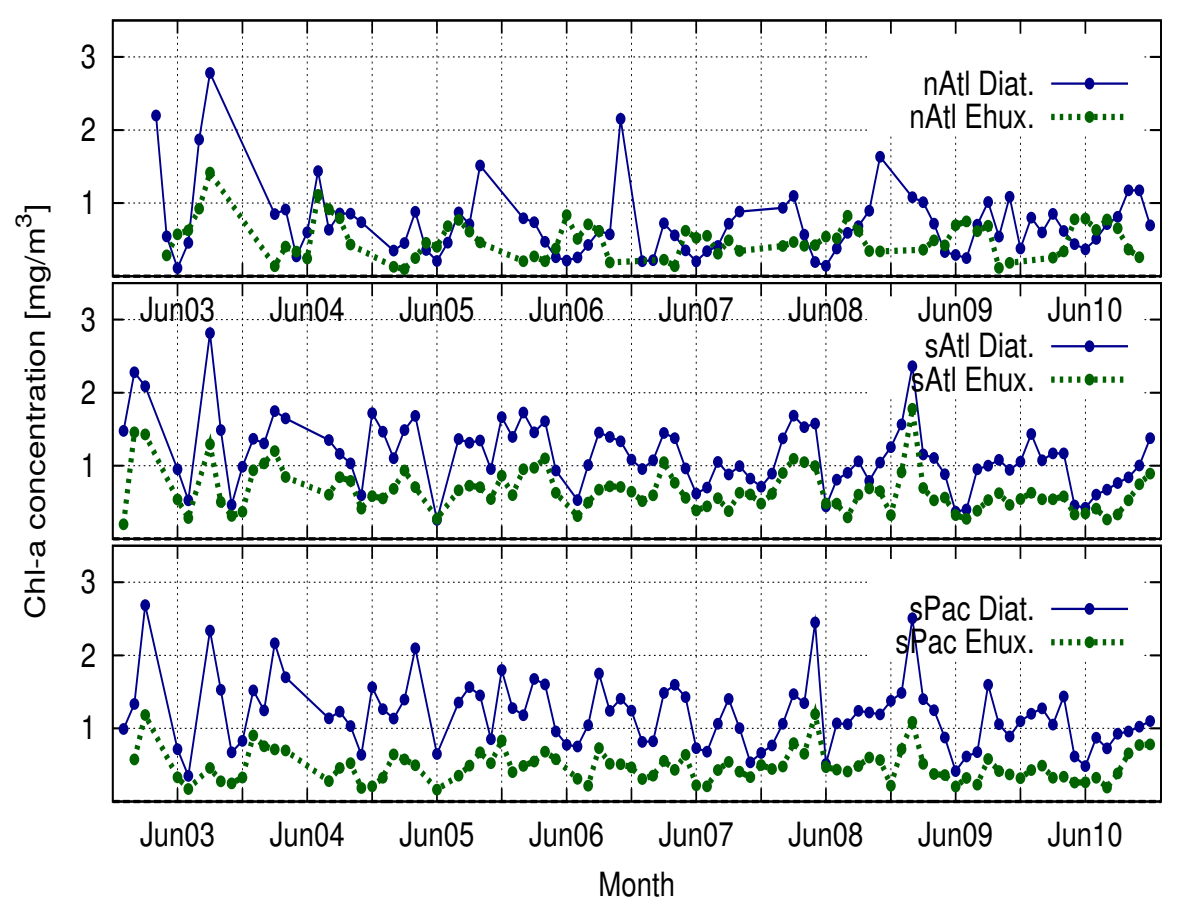

Fig. 9. Times series of the PhytoDOAS diatoms (blue solid lines) and coccolithophores (green dashed lines) - both presented as chl $a$ conc. - in three study regions: nAtl (upper panel), sAtl (middle panel) and sPac (lower panel).

Table 1. MLD trends in selected regions.

\begin{tabular}{lrr}
\hline Region & Simple trend & Anomaly trend \\
\hline nAtl & -0.660 & 0.050 \\
sAtl & -0.219 & -0.271 \\
sPac & -0.081 & -0.232 \\
\hline
\end{tabular}

Considering the simple trend values (Fig. 10 left panel), coccolithophores grew negligibly in nAtl and chl $a$ decreased in the two southern regions at different rates; total chl $a$ increased in all regions; PIC decreased strongly in nAtl and sAtl, while it strongly increased in sPac. This may have been caused by the strong SST-rise in the Tasman Sea (Tilburg et al., 2002), even though this SST rise was not observed in our sPac simple trend; however, the decreasing rate of SST in sAtl and sPac was clearly followed consistently by the decrease of coccolithophores; and the rate of increase of SST in nAtl was associated, at a small rate, with the increase of coccolithophores. The surface wind-speed decreased in nAtl and sPac, while they slightly increased in sAtl. Only in nAtl was the decreasing rate of wind-speed associated with an increasing rate of coccolithophores. Considering that there is also no constant relationship between rates of change of wind-speed and PIC in the three regions, it can be inferred that in the studied time-scale of about one decade, the rate of change of coccolithophores was not determined by the rate of wind- speed. Comparing the values of the simple trend with the anomaly trend values (Fig. 10 left panel), both showed similar results. Only the SST anomaly trends were different, especially in sAtl and sPac, where the trends were even reversed. To summarize, the results were comparable and the anomaly trend was more appropriate, because it removed completely the seasonal effect.

\subsection{Climatology analysis}

Figure 11 illustrates the climatology curves for the corresponding six parameters in the three selected regions. Each data point here depicts the mean value of a certain month over eight-year data of the respective time series. In nAtl, the coccolithophores reached their maximum in August, whereas in sAtl and sPac two maxima were reached annually: a smaller one in austral spring (between September and October) and a higher one in austral summer (between February and March). The occurrences of two coccolithophore blooms annually in the Southern Hemisphere has been reported before (Balch et al., 2011), as well as the mid-summer coccolithophore blooms in nAtl (Brown and Yoder, 1994b; Tyrrell and Taylor, 1996). In sPac these maxima were not as pronounced, showing another weak maximum in May. This may have been caused by the effect of large eddies existing in the Tasman Sea. However, the coccolithophore maximum in austral spring in sPac was also observed by studying SeaWiFS data (Tilburg et al., 2002). 

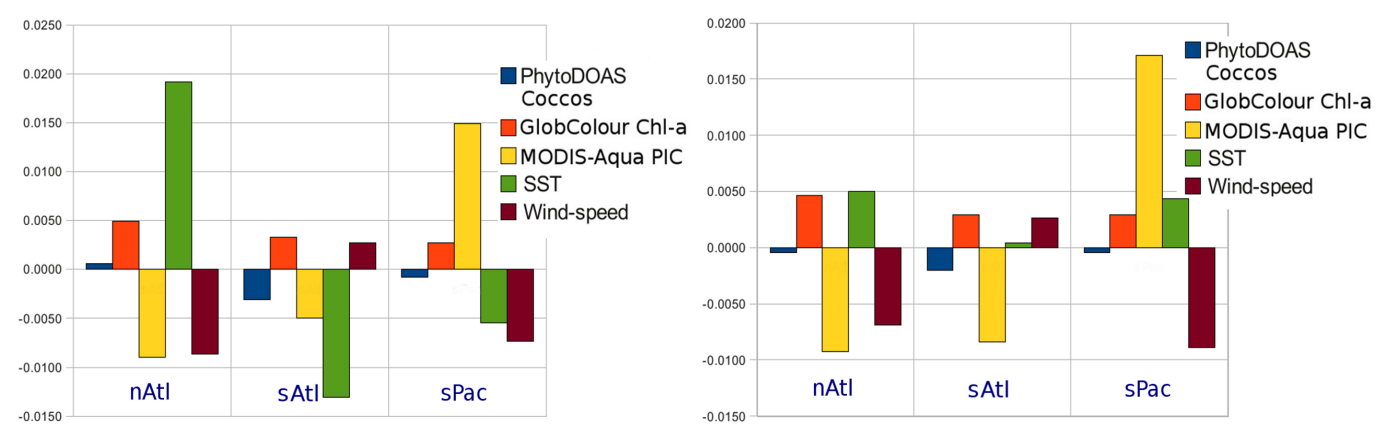

Fig. 10. Linear trends of five monitored parameters over eight years of data (2003 to 2010) for the biologically productive months. The left panel shows values of the simple trends, while the right panel shows values of the anomaly trends. Each panel contains the results of three study regions: nAtl (left), sAtl (middle) and sPac (right). In both approaches only the regional spring and summer months were considered: April to September for nAtl and September to March for sAtl and sPac. The chart does not include the MLD trends, due to their different ranges, which are much higher in order of magnitude.

The GlobColour total chl $a$ showed an annual peak spreading over spring and summer, with two weak shoulders in nAtl (higher in June and a smaller in August), one wide peak in sAtl from October to January and only a minor peak in sPac from October to February. These results in nAtl and sAtl suggest that the coccolithophores are the dominant phytoplankton group succeeding the main bloom in late summer, which again supports the argument that coccolithophores are favored when nutrients are depleted. However, the almost flat curve of GlobColour total chl $a$ in sPac is not consistent with SeaWiFS results presented in Tilburg et al. (2002) for the Tasman Sea. The MODIS-Aqua PIC showed five months (May to September) of enhanced conc. in nAtl with two pronounced shoulders in June and August, coinciding temporally with the maxima of GlobColour total chl $a$, while only the latter peak was coinciding with the coccolithophore annual maximum. This may indicate that either during the first total chl $a$ peak (in June) coccolithophores were contributing significantly to the biomass and the PhytoDOAS algorithm is underestimating the coccolithophore chl $a$, or the PIC algorithm functions are partly incorrect for this region. The PIC climatology curves in sAtl and sPac varied quite smoothly (similar to each other), with a peak in December/January, which is more pronounced in sAtl. The patterns of PIC climatology in these regions followed the GlobColour total chl $a$ between March and October. The climatology curves of MLD, SST and wind-speed clearly supported the expected geophysical conditions for the formation of coccolithophore blooms.

\section{Conclusions}

We studied the developments of coccolithophore and total phytoplankton blooms and PIC conc. in three selected regions from January 2003 to December 2010 with satellite data. The time series of these three phytoplankton-based products revealed the seasonal bloom cycles in a regular order, with fairly good agreement to each other. In the nAtl one coccolithophore maximum was regularly observed in the mid-summer, while in the sAtl and sPac two maxima in austral spring and summer occurred. The maxima for total chl $a$ and PIC conc. were during the same time period, but in both hemispheric regions only appeared once per year over a longer time period (4-5 months). The results showed that the coccolithophore blooms generally dominated the total phytoplankton maxima in late summer (August/September in nAtl and February/March in two other regions). In the nAtl and sAtl regions, the maximum concentrations were comparable for all three parameters, while they were much lower $(70-50 \%)$ in the sPac regions. Comparisons to time series of geophysical parameters clearly showed that the surface phytoplankton biomass was related to shallow MLDs, low wind-speed, and high and sharp-rising SSTs. Overall, the consistency of the three ocean color data products was better in nAtl, as compared to sAtl and sPac. The major environmental factors affecting the Patagonian Shelf and the Tasman Sea have been briefly mentioned, in order to address the possible causes of turbulent and mixing effects in sAtl and sPac, respectively. The specific regional characteristics in sAtl and sPac probably cause effects in smaller time scales than a month. However, our time series study had to be limited to the monthly resolution because of the coarse spatial resolution and limited global coverage of the available hyper-spectral satellite data used for the PhytoDOAS coccolithophore retrieval. Applying the PhytoDOAS method to upcoming hyper-spectral satellite sensors, e.g. the Sentinel5-Precursor (planned to launch in 2014) with $7 \times 7 \mathrm{~km}^{2}$ pixel size and global coverage within two days, will allow the weekly-based monitoring of the dynamics of such phytoplankton blooms.

The outcome of the study indicates that the PhytoDOAS method potentially enables the quantitative detection of the 


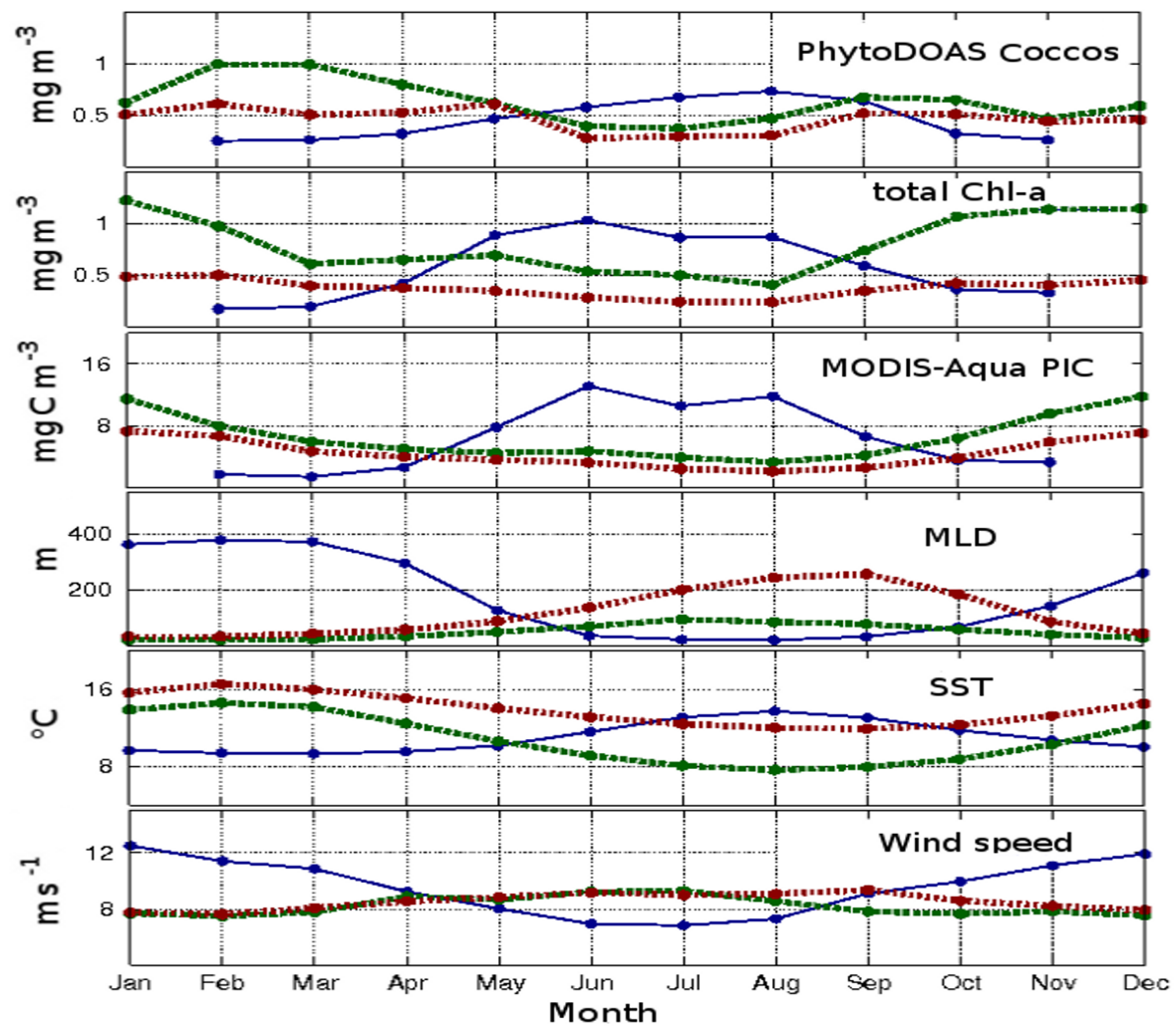

Fig. 11. Climatology curves of all monitored parameters in three selected regions. Each slot contains the climatologies of a certain parameter in three regions, which are denoted as follows: nAtl (blue line), sAtl (green dashed-line) and sPac (red dashed-line). The slots have been arranged in the same order as before, showing following parameters downward: PhytoDOAS coccolithophore chl $a$; GlobColour total chl $a$; MODIS-Aqua PIC conc.; MLD; SST; and surface wind-speed.

living coccolithophore cells (in terms of chl $a$ conc.), even though the final achievement depends on validating of the results with in-situ measurements, which might in turn demand more modifications to the method. The results showed similar patterns to the distributions of coccolithophore-PIC product of MODIS-Aqua, as well as showed consistency with the environmental conditions associated with coccolithophore blooms. However, there are still sources of uncertainties in the retrieval to be accounted for, e.g. the spatial variations in the absorption spectra. It should be noted that this product is based on a new retrieval method, which compared to the usual empirical algorithms has less dependency on the biological a-priori data. This retrieval method can be reliably used for remote identification of coccolithophores and tracking its bloom developments in the global ocean. For better analysis and interpretation of the results, more investigations on the geophysical parameters that rule the regional climate, as well as on the local biological conditions, will be done for each region. For instance, due to the importance of light for the formation of coccolithophore blooms (Nanninga and Tyrrell, 1996), the variation in solar radiation must be included (e.g. regional time series of water leaving radiance at $555 \mathrm{~nm}$, as referred to by Raitsos et al.,
2006). Finding the regional variations of nutrient regime, especially phosphate and nitrate, using appropriate modeled data, is another supplementary work to be accomplished. Regional adaptations of the PhytoDOAS coccolithophore retrieval are planned in order to account for the geographical variations in specific absorptions with respect to the dominating coccolithophore species. In general, to avoid the uncertainties associated with the spatial variations in phytoplankton absorption, an alternative approach would be to establish a multi-regional PhytoDOAS retrieval, using different sets of PFTs' absorption spectra, representing the main regions. For this purpose, the biogeographical provinces presented by Longhurst (1998) could provide a good criterion for dividing the world oceans into the retrieval regions. The PhytoDOAS coccolithophore data will be validated with available in-situ measurements. The data shall also be compared with chl $a$ conc. of haptophytes inferred from HPLC pigment analysis. However, in-situ data also have to be treated with care, because they either only consider the large coccolithophore cells via microscopic techniques or, as for the HPLC-based methods, also involve other haptophyte species besides coccolithophores. Moreover, matching the in-situ point measurements to the large satellite ground pixels is always a 
challenging task. Time series studies for other regions of particular interest (e.g. Bering Sea) are planned in order to assess the overall global picture of coccolithophore distributions.

Acknowledgements. We are thankful to ESA, DLR, and the SCIAMACHY Quality Working Group (SQWG) for providing us with SCIAMACHY level-1 data. We thank NASA-GSFC for MODIS PIC images and data. We are grateful to NASA and ESA, particularly to the GlobColour project, for processing and supplying satellite total chl $a$ data. We are thankful to AVHRR for providing the SST data, AMSR-E for the surface wind-speed products and also Oregan State University for the FNMOC MLD data. We thank Sebastian Rocitta (AWI) for providing us cultures of Gephyrocapsa and E. huxleyi, Sonja Wiegmann (AWI) and Marta Kaspar (AWI) for assistance with the absorption measurements and Christoph Voelker (AWI) for his valuable comments. Funding was provided by the HGF Innovative Network Funds (Phytooptics). Funding for TD was supplied via the EU project SHIVA-226224FP7-ENV-2008-1. This work is a contribution to the "Earth System Science Research School (ESSReS)", an initiative of the Helmholtz Association of German research centers (HGF) at the Alfred Wegener Institute for Polar and Marine Research. Many thanks to Klaus Grosfeld, the coordinator of ESSReS, for supplementary supports to the first author.

Edited by: E. Boss and A. Bricaud

\section{References}

Ackleson, S. G., Balch, W. M., and Holligan, P. M.: White waters of the Gulf of Maine, Oceanography, 1, 18-22, 1988.

Ackleson, S., Balch, W. M., and Holligan, P. M.: Response of water leaving radiance to particulate calcite and chlorophyll $a$ concentrations: A model for Gulf of Maine coccolithophore blooms, J. Geophys. Res., 99, 7483-7499, 1994.

Alvain, S., Moulin, C., Dandonneau, Y., and Breon, F. M.: Remote sensing of phytoplankton groups in case 1 waters from global SeaWiFS imagery, Deep-Sea Res. I, 52, 1989-2004, 2005.

Andreae, M. O.: Ocean-atmosphere interactions in the global biogeochemical sulfur cycle, Marine Chem., 30, 1-29, 1990.

Balch, W. M., Eppley, R. W., Abbott, M. R., and Reid, F. M. H.: Bias in satellite-derived pigment measurements due to coccolithophores and dinoflagellates, J. Plankton Res., 11, 575-581, 1989.

Balch, W. M.: Re-evaluation of the physiological ecology of coccolithophores, in: Coccolithophores. From Molecular Processes to Global Impact, edited by: Thierstein, H. R. and Young, J. R., Springer-Verlag, Berlin, 165-190, 2004.

Balch, W. M. and Utgoff, P. E.: Potential Interactions Among Ocean Acidification, Coccolithophores, and the Optical Properties of Seawater, Oceanography, 22, 146-159, 2009.

Balch, W. M., Holligan, P. M., Ackleson, S. G., and Voss, K. J.: Biological and optical properties of mesoscale coccolithophore blooms in the Gulf of Maine, Limnol. Oceanogr., 36, 629-643, 1991.

Balch, W. M., Gordon, H. R., Bowler, B. C., Drapeau, D. T., and Booth, E. S.: Calcium carbonate measurements in the surface global ocean based on Moderate-Resolution Imag- ing Spectroradiometer data, J. Geophys. Res., 110, C07001, doi:10.1029/2004JC002560, 2005.

Balch, W. M., Drapeau, D. T., Bowler, B. C., Lyczskowski, E., Booth, S., and Alley, D.: The contribution of coccolithophores to the optical and inorganic carbon budgets during the Southern Ocean Gas Exchange Experiment: New evidence in support of the Great Calcite Belt hypothesis, J. Geophys. Res., 116, C00F06, doi:10.1029/2011JC006941, 2011.

Bianchi, A. A., Bianucci, L., Piola, A. R., Pino, D. R., Schloss, I., Poisson, A., and Balestrini, C. F.: Vertical strati cation and airsea $\mathrm{CO}_{2}$ fluxes in the Patagonian Shelf, J. Geophys. Res., 110, C07003, doi:10.1029/2004JC002488, 2005.

Bianchi, A. A., Pino, D. R., Perlender, H. G. I., Osiroff, A. P., Segur, V., Lutz, V., Clara, M. L., Balestrini, C. F., and Piola, A. R.: Annual balance and seasonal variability of sea-air $\mathrm{CO}_{2}$ fluxes in the Patagonia Sea: their relationship with fronts and chlorophyll distribution, J. Geophys. Res., 114, C03018, doi:10.1029/2008JC004854, 2009.

Blackburn, S. I. and Cresswell, G.: A coccolithophorid bloom in Jervis Bay, Australia, Australian J. Mar. Freshwater Res., 44, 253-260, 1993.

Boss, E. and Behrnfeld, M.: In situ evaluation of the initiation of the North Atlantic phytoplankton bloom, Geophys. Res. Lett., 37, L18603, doi:10.1029/2010GL044174, 2010.

Bovensmann, H., Burrows, J. P., Buchwitz, M., Frerick,J., Noel, S., Rozanov,V. V., Chance, K. V., and Goede, A. P. H.: SCIAMACHY - Mission objectives and measurement modes, J. Atmos. Sci., 56, 127-150, 1999.

Bracher, A., Vountas, M., Dinter, T., Burrows, J. P., Röttgers, R., and Peeken, I.: Quantitative observation of cyanobacteria and diatoms from space using PhytoDOAS on SCIAMACHY data, Biogeosciences, 6, 751-764, doi:10.5194/bg-6-751-2009, 2009.

Brandini, F. P., Boltovskoy, D., Piola, A., Kocmur, S., Rottgers, R., Abreu, P. C., and Lopes, R. M.: Multiannual trends in fronts and distribution of nutrients and chlorophyll in the southwestern Atlantic (30-62 S), Deep-Sea Res. I, 47, 1015-1033, 2000.

Broecker, W. S. and Peng, T. H.: Tracers in the Sea, Eldigio, Palisades, New York, 1982.

Brown, C. W.: Global Distribution of coccolithophore blooms, Oceanography, 8, 59-60, 1995.

Brown, C. W. and Podesta, G. P.: Remote sensing of coccolithophore blooms in the western South Atlantic Ocean, Remote Sens. Environ., 60, 83-91, 1997.

Brown, C. W. and Yoder, J. A.: Coccolithophorid blooms in the global ocean, J. Geophys. Res., 99, 7467-7482, 1994a.

Brown, C. W. and Yoder, J. A.: Distribution pattern of coccolithophorid blooms in the western North Atlantic, Cont. Shelf Res., 14, 175-197, 1994b.

Burns, D. A.: Phenotypes and dissolution morphotypes of the genus Gephyrocapsa Kamptner and Emiliania huxleyi (Lohmann), N.Z. J. Geol. Geophys., 20, 143-155, 1977.

Cai, W., Shi, G., Cowan, T., Bi, D., and Ribbe, J.: The response of the Southern Annular Mode, the East Australian Current, and the southern mid-latitude ocean circulation to global warming, Geophys. Res. Lett., 32, L23706, doi:10.1029/2005GL024701, 2005.

Carder, K. L., Chen, F. R., Cannizzaro, J. W., Campbell, J. W., and Mitchell, B. G.: Performance of the MODIS semi-analytical ocean color algorithm for chlorophyll $a$, Adv. Space Res., 33, 
1152-1159, 2004.

Charlson, R. J., Lovelock, J. E., Andreae, M. O., and Warren, S. G.: Oceanic phytoplankton, atmospheric sulfur, cloud albedo and climate, Nature, 326, 655-661, doi:10.1038/326655a0, 1987.

Clark, D. R., Flynn, K. J., and Owens, N. J. P.: The large capacity for dark nitrate-assimilation in diatoms may overcome nitrate limitation of growth, New Phytol., 155, 101-108, 2002.

Erickson, D. J., Hernandez, J. L., Ginoux, P., Gregg, W. W., McClain, C., and Christian, J.: Atmospheric iron delivery and surface ocean biological activity in the Southern Ocean and Patagonian region, Geophys. Res. Lett., 30, 1609, doi:10.1029/2003GL017241, 2003.

Eynaud, F., Giraudeau, J., Pichon, J.-J., and Pudsey, C. J.,: Seasurface distribution of coccolithophores, diatoms, silicoflagellates and dinoflagellates in the South Atlantic Ocean during the late austral summer 1995, Deep-Sea Res. I, 46, 451-482, 1999.

Falkowski, P. G., Barber, R. T., and Smetacek, V.: Biogeochemical controls and feedbacks on ocean primary production, Science, 281, 200-206, 1998.

Garcia, C. A. E., Garcia, V. M. T., Dogliotti, A. I., Ferreira, A., Romero, S. I., Mannino, A., Souza, M. S., and Mata, M. M.: Environmental conditions and bio-optical signature of a coccolithophorid bloom in the Patagonian shelf, J. Geophys. Res., 116, C03025, doi:10.1029/2010JC006595, 2011.

Goldman, J. C.: Potential role of large oceanic diatoms in new primary production, Deep-Sea Res. I, 40, 159-168, 1993.

Goldman, J. C. and McGillicuddy, D. J.: Effect of large marine diatoms growing at low light on episodic new production, Limnol. Oceanogr., 48, 1176-1182, 2003.

Gordon, A. L.: Brazil Malvinas Conuence-1984, Deep-Sea Res., 36, 359-384, 1989.

Gordon, H. R. and Morel, A.: Remote assessment of ocean color for interpretation of satellite visible imagery: A review, SpringerVerlag, New York, 1983.

Gordon, H. R., Brown, O. B., Evans, R. H., Brown, J. W., Smith, R. C., Baker, K. S., and Clark, D. K.: A semi-analytic radiance model of ocean color, Geophys. Res., 93, 10909-10924, 1988.

Gordon, H. R., Boynton, G. C., Balch, W. M., Groom, S. B., Harbour, D. S., and Smyth, T. J.: Retrieval of Coccolithophore from SeaWiFS Imagery Calcite Concentration, Geophys. Res. Lett., 28, 1587-1590, 2001.

Gregg, W. W. and Casey, N. W.: Modeling coccolithophores in the global oceans, Deep Sea Res. II, 54, 447-477, 2007.

Gregg, W. W., Ginoux, P., Schopf, P. S., and Casey, N. W.: Phytoplankton and iron: validation of a global three-dimensional ocean biogeochemical model, Deep Sea Res. II, 50, 3147-3169, 2003.

Groom, S. and Holligan, P. M.: Remote sensing of coccolithophore blooms, Adv. Space Res., 7, 73-78, doi:10.1016/02731177(87)90166-9, 1987.

Hays, G. C.: Zooplankton avoidance activity, Nature, 376, p. 650, doi:10.1038/376650a0, 1995.

Holligan, P. M., Viollier, M., Harbour, D. S., and ChampagnePhilipe, M.: Satellite and ship studies of coccolithophore production along a continental shelf-edge, Nature, 304, 339-342, 1983.

Holligan, P. M., Fernandez, E., Aiken, J., Balch, W. M., Boyd, P., Burkill, P. H., Finch, M., Groom, S. B., Malin, G., Muller, K., Purdie, D. A., Robinson, C., Trees, C. C., Turner, S. M., and Van der Wal, P.: A biogeochemical study of the coccolithophore Emiliania huxleyi in the north Atlantic, Global Biogeochem. Cy.,
7, 879-900, 1993.

Keller, M. D., Bellows, W. K., and Guillard, R. R. L.: Dimethylsulfide production and marine phytoplankton: an additional impact of unusual blooms, in: Novel phytoplankton blooms, edited by: Cosper, E. M., Bricelj, V. M., and Carpenter, E. J., SpringerVerlag, New York, 101-115, 1989b.

Koepke, P.: Effective reflectance of oceanic whitecaps, Appl. Opt., 23, 1816-1824, doi:10.1364/AO.23.001816, 1984.

Lochte, K., Ducklow, H. W., Fasham, M. J. R., and Stienen, C.: Plankton succession and carbon cycling at 47-Degrees-N-20Degrees-W during the JGOFS North Atlantic Bloom Experiment, Deep-Sea Res. II, 40, 91-114, 1993.

Longhurst, A. R.: Seasonal cycles of pelagic production and consumption, Prog. Oceanogr., 36, 77-167, 1995.

Longhurst, A. R.: Ecological geography of the sea. Academic Press: San Diego, ISBN 0-12-455559-4, 1998.

Malin, G., Turner, S. M., and Liss, P. S.: Sulfur. the plankton-climate connection, J. Phycol., 28, 590-597, 1992.

Margalef, R.: Life-forms of phytoplankton as survival alternatives in an unstable environment, Oceanologica Acta, 1, 493-509, 1978.

Milliman, J. D.: Production and accumulation of calcium in the ocean, Global Biogeochem. Cy., 7, 927-957, 1993.

Morozov, E., Korosov, A., Pozdnyakov, D., Pettersson, L., and Sychev, V.: A new area-specific bio-optical algorithm for the Bay of Biscay and assessment of its potential for SeaWiFS and MODIS/Aqua data merging, Int. J. Remote Sens., 31, 65416565, 2010.

Nair, A., Sathyendranath, S., Platt, T., Morales, J., Stuart, V., Forget, M.-H., Devred, E., and Bouman, H.: Remote sensing of phytoplankton functional types, Remote Sens. Environ., 112, 33663375, 2008.

Nanninga, H. J. and Tyrrell, T.: Importance of light for the formation of algal blooms by Emiliania huxleyi, Mar. Ecol.-Prog. Ser., 136, 195-203, 1996.

Neuheimer, A. B., Thresher, R. E., Lyle, J. M., and Semmens, J. M.: Tolerance limit for fish growth exceeded by warming waters, Nature Climate Change, 1, 110-113, doi:10.1038/nclimate1084, 2011.

Oliveira, L. R., Piola, A. R., Mata, M. M., and Soares, I. D.: Brazil Current surface circulation and energetics observed from drifting buoys, J. Geophys. Res., 114, C10006, doi:10.1029/2008JC004900, 2009.

O'Reilly, J. E., Maritorena, S., Mitchell, B. G., Siegel, D. A., Carder, K. L., Garver, S. A., Kahru, M., and McClain, C.: Ocean color chlorophyll algorithms for SeaWiFS, J. Geophys. Res., 103, 24937-24953, 1998.

Painter, S. C., Poulton, A. J., Allen, J. T., Pidcock, R., and Balch, W. M.: The COPAS'08 expedition to the Patagonian Shelf: Physical and environmental conditions during the 2008 coccolithophore bloom, Cont. Shelf Res., 30, 1907-1923, 2010.

Perner, D. and Platt, U.: Detection of nitrous acid in the atmosphere by differential optical absorption, Geophys. Res. Lett., 93, 917920, 1979.

Platt, U.: Differential optical absorption spectroscopy (DOAS), in: Air monitoring by Spectroscopic Techniques, edited by: Sigrist, M., John Wiley \& Sons, Inc., 27-84, 1994.

Raitsos, D. E., Lavender, S. J., Pradhan, Y., Tyrrell, T., Reid, P. C., and Edwards, M.: Coccolithophore bloom size variation in re- 
sponse to the regional environment of the subarctic North Atlantic, Limnol. Oceanogr., 51, 2122-2130, 2006.

Raven, J. A. and Falkowski, P. G.: Oceanic sinks for atmospheric $\mathrm{CO}_{2}$, Plant Cell Environ., 22, 741-755, 1999.

Rhodes, L. L., Peake, B. M., MacKenzie, A. L., and Marwick, S.: Coccolithophores Gephyrocapsa oceanica and Emiliania huxleyi (Prymnesiophyceae $=$ Haptophyceae) in New Zealand's coastal waters: Characteristics of blooms and growth in laboratory culture, New Zealand Journal of Marine and Freshwater Research, 29, 345-357, 1995.

Ridgway, K. R.: Long-term trend and decadal variability of the southwardpenetration of the East Australian Current, Geophys. Res. Lett., 34, L13613, doi:10.1029/2007GL030393, 2007.

Riebesell, U., Zondervan,I., Rost, B., Tortell, P. D., Zeebe, R. E., and Morel, F. M. M.: Reduced calcification of marine plankton in response to increased atmospheric $\mathrm{CO}_{2}$, Nature, 407, 364-367, doi:10.1038/35030078, 2000.

Romero, S. I., Piola, A. R., Charo, M., and Garcia, C. A. E.: Chlorophyll-a variability off Patagonia based on SeaWiFS data, J. Geophys. Res., 111, C05021, doi:10.1029/2005JC003244, 2006.

Rost, B. and Riebesell, U.: Coccolithophores and the biological pump: Responses to environmental changes, in: Coccolithophores, from molecular processes to global impact, edited by: Thierstein, H. R. and Young, J. R., 99-126, Springer, New York, 2004.

Sabatini, M. E., Reta, R., and Matano, R.: Circulation and zooplankton biomass distribution over the southern Patagonian shelf during late summer, Cont. Shelf Res., 24, 1359-1373, doi:10.1016/j.csr.2004.03.014, 2004.

Sadeghi, A., Dinter, T., Vountas, M., Taylor, B., Peeken, I., and Bracher, A.: Improvements to the PhytoDOAS method for identification of major phytoplankton groups using hyperspectral satellite data, Ocean Sci. Discuss., 8, 2271-2311, doi:10.5194/osd-8-2271-2011, 2011.

Saraceno, M., Provost, C., Piola, A. R., Bava, J., and Gagliardini, A.: Brazil Malvinas Frontal System as seen from 9 years of advanced very high resolution radiometer data, J. Geophys. Res., 109, C05027, doi:10.1029/2003JC002127, 2004.

Sathyendranath, S., Watts, L., Devred, E., Devred, E., Platt, T., Caverhill, C., and Maass, H.: Discrimination of diatoms from other phytoplankton using ocean-colour data, Mar. Ecol. Prog. Ser., 272, 59-68, 2004.

Schloss, I. R., Ferreyra, G. A., Ferrario, M. E., Almandoz, G. O., Codna, R., Bianchi, A. A., Balestrini, C. F., Ochoa, H. A., Pino, D. R., and Poisson, A.: Role of plankton communities in sea-air variations in $\mathrm{pCO}_{2}$ in the SW Atlantic Ocean, Mar. Ecol. Prog. Ser., 332, 93-106, 2007.

Smetacek, V., Klaas, C., Menden-Deuer, S., and Rynearson, T. A.: Mesoscale distribution of dominant diatom species relative to the hydrographical field along the Antarctic Polar Front, Deep-Sea Res. II, 49, 3835-3848, 2002.

Smyth, T. J., Tyrrell, T., and Tarrant, B.: Time series of coccolithophore activity in the Barents Sea, from twenty years of satellite imagery, Geophys. Res. Lett., 31, L11302, doi:10.1029/2004GL019735, 2004.
Spadone, A. and Provost, C.: Variations in the Malvinas Current volume transport since October 1992, J. Geophys. Res., 114, C02002, doi:10.1029/2008JC004882, 2009.

Subramaniam, A., Brown, C. W., Hood, R. R., Carpenter, E. J., and Capone, D. G.: Detecting Trichodesmium blooms in SeaWiFS imagery, Deep-Sea Res. II, 49, 107-121, 2002.

Thierstein, H. R. and Young, J. R.: Coccolithophores From Molecular Processes to Global Impact, Springer, New York, 2004.

Tilburg, C. E., Subrahmanyam, B., and O'Brien, J. J.: Ocean color variability in the Tasman Sea, Geophys. Res. Lett., 29, 14871481, doi:10.1029/2001GL014071, 2002.

Tyrrell, T. and Merico, A.: Emiliania huxleyi: Bloom observations and the conditions that induce them, 75-97, in: Coccolithophores from molecular processes to global impact, edited by: Thierstein, H. R. and Young, J. R., Springer, New York, 2004.

Tyrrell, T. and Taylor, A. H.: A modelling study of Emiliania huxleyi in the NE Atlantic, J. Mar. Syst., 9, 83-112, 1996.

Tyrrell, T., Holligan, P. M., and Mobley, C. D.: Optical impacts of oceanic coccolithophore blooms, J. Geophys. Res., 104, 32233241, 1999.

Van der Linden, W. J. M.: Extinct mid-ocean ridges in the Tasman sea and in the Western Pacific, Earth Planet. Sci. Lett., 6, 483490, 1969.

Vountas, M., Richter, A., Wittrock, F., and Burrows, J. P.: Inelastic scattering in ocean water and its impact on trace gas retrievals from satellite data, Atmos. Chem. Phys., 3, 1365-1375, doi:10.5194/acp-3-1365-2003, 2003.

Vountas, M., Dinter, T., Bracher, A., Burrows, J. P., and Sierk, B.: Spectral studies of ocean water with space-borne sensor SCIAMACHY using Differential Optical Absorption Spectroscopy (DOAS), Ocean Sci., 3, 429-440, doi:10.5194/os-3-429-2007, 2007.

Westbroek, P., De Vring-De Jong, E. W., Van Der Wal, P., Borman, A. H., and De Vring, J. P. M.: Biopolymer-mediated Ca and Mn accumulation and biomineralization, Geol. Mijnbouw, 64, 5-15, 1985.

Westbroek, P., Brown, C. W., Van-Bleijswijket, J., Brownlee, C., Brummer, G. J., Conte, M., Egge, J., Fernandez, E., Jordan, R. W., Knappertsbusch, M., Stefels, J., Veldhuis, M., Van-der-Wal, P., and Young, J. R.: A model approach to biological climate forcing. The example of Emiliania huxleyi, Global Planet. Change, 8, 27-46, 1993.

Winder, M. and Cloernet, J. E.: The annual cycles of phytoplankton biomass, Philos. Trans. Roy. Soc., 365, 3215-3226, 2010.

Yoder, J. A., McClain, C. R., Feldman, G. C., and Esaias, W. E.: Annual cycles of phytoplankton chlorophyll concentrations in the global ocean: a satellite view, Global Biogeochem. Cy., 7, 181193, 1993.

Zhang, X., Lewis, M., Lee, M., Johnson, B., and Korotaev, G.: The volume scattering function of natural bubble populations, Limnol. Oceanogr., 47, 1273-1282, doi:10.4319/lo.2002.47.5.1273, 2002. 